\title{
ENVIRONMENTAL INDICATORS OF WATER QUALITY IN THE CIBIN RIVER (TRANSYLVANIA, ROMANIA)
}

\author{
Ramona IANCU *, Letitia OPREAN*, Diana STEGÄRUŞ **, \\ Ovidiu TIŢA *, Adrian BOICEAN *** and Ecaterina LENGYEL *
}

\begin{abstract}
* "Lucian Blaga" University of Sibiu, Faculty of Agricultural Sciences, Food Industry and Environmental Protection, Department of Biotechnologies, Raţiu Street 7-9, Sibiu, Sibiu County, Romania, RO-550012, ramy11us@yahoo.com, letitia.oprean@ulbsibiu.ro, ovidiu.tita@ulbsibiu.ro, ecaterina.lengyel@ulbsibiu.ro

** National Research-Development Institute for Cryogenic and Isotopic Technologies, 4 Uzinei Street, O. P. 4, C. P. 10, RO-240050, Râmnicu Vâlcea, Romania, bociu_diana@yahoo.com

*** Academic Emergency Hospital, 2-4 Corneliu Coposu Bvd., RO-550245, Sibiu Romania, adrian.boicean@gmail.com
\end{abstract}

KEYWORDS: water, pollution, physical-chemical tests, Cibin River, Transylvania, Romania.

\section{ABSTRACT}

Water pollution has become a worldwide problem and its influence over the health of human populations grows every day. This study was carried out to determinate the rate level of pollution of the Cibin River (Transylvania, Romania) via physical-chemical and microbiological tests. Water samples were measured at six different locations along the Cibin River for a period of 12 months. Analysis methods used to determine physical-chemical quality indices for water were as follows: $\mathrm{O}_{2}$ - ISO 5814/99, $\mathrm{pH}$ - SR ISO 10523-97, $\mathrm{PO}^{4-} \mathrm{KIT}$ Merck, $\mathrm{SO}^{4-}$ - PS/LE 17, conductivity - Sonda, $\mathrm{NH}_{4+}$ - SR ISO 7150-1/2001, $\mathrm{NO}_{3-}-\mathrm{SR}$ ISO 7890/2000, $\mathrm{NO}_{2-}$ - SR EN 26777 - ISO 6777/2002, chlorides - SR ISO 9297/2001, CCOCr SR ISO 6060/96, $\mathrm{CBO}_{5}$ - SR ISO 5815/95, suspended solids - STAS 6953/81, residues - STAS $9187 / 95$. The water samples were analyzed also from a sanitary and public health point of view, for example: total number of mesophilic bacteria, total number of yeasts and moulds, total coliforms, total fecal coliforms, Enterococcus and Escherichia coli, according to current Romanian legislation and normatives (Order 1146/2002). The significant results place the river in the first (sampling stations 1,2 and 3) and second (sampling stations 4,5 and 6) water Quality Class. Due to the fact that the upper dam reservoir at Gura Râului is the main source of drinking water for Sibiu, it is certain that this water presents optimal characteristics for human consumption and is thus declared to be one of the healthiest water sources in Romania.

ZUSAMMENFASSUNG: Umweltindikatoren der Wasserqualität des Zibin-Flusses (Transylvanien, Rumänien).

Die Wasserverschmutzung ist zu einem globalen Problem geworden und ihr Einfluss auf die Gesundheit der Bevölkerung wächst von Tag zu Tag. Die vorliegende Forschung hatte zum Ziel, den Verschmutzungsgrad des Zibin-Flusses (Rumänien) mit Hilfe physikalischchemischer und mikrobiologischer Teste zu ermitteln. Die Wasserproben wurden von sechs verschiedenen Stellen entlang des Zibins über eine Zeitspannne von 12 Monaten entnommen. Die Analysemethoden für die zur Bestimmung der physikalisch-chemischen 
Wasserqualitätszeiger waren wie folgt gekennzeichnet: $\mathrm{O}_{2}$ - ISO 5814/99, pH - SR ISO 1052397, $\mathrm{PO}^{4-}$ KIT Merck, SO ${ }^{4-}$ - PS/LE 17, Leitfähigkeits-Sonde, $\mathrm{NH}_{4+}$ - SR ISO 7150-1/2001, $\mathrm{NO}_{3-}$ - SR ISO 7890/2000, $\mathrm{NO}_{2-}$ - SR EN 26777, - ISO 6777/2002, Chlor - SR ISO 9297/2001, CCOCr - SR ISO 6060/96, $\mathrm{CBO}_{5}$ - SR ISO 5815/95, Schwebstoffe - STAS 6953/81, Rückstände - STAS 9187/95. Die Wasserproben wurden auch von sanitärem Standpunkt und jenem der öffentlichen Gesundheit mikrobiologisch untersucht und zwar: die Gesamtzahl der mesophilen Bakterien, der Hefen und Schimmelpilze, die der Coliformen und der Fäkalcoliformen Enterococcus und Escherichia coli, gemäß der derzeit in Rumänien gültigen Gesetzgebung und Regelungen (Erlass 1146/2002). Die signifikanten Ergebnisse der Untersuchung gliedern den Zibin in: einen Abschnitt der Qualitätsklasse I. (Entnahmepunkte 1, 2 und 3) und einen Abschnitt der Qualitätsklasse II (Probestellen/Entnahmepunkte 4, 5 und 6). Da der Stausee von Gura Râului die Hauptversorgung an Trinkwasser für die Stadt Sibiu/Hermannstadt gewährleistet, ist sichergestellt, dass das Wasser von Gura Râului optimale Eigenschaften für Trinkwasserversorgung aufweist und sogar zu einem der landesweit gesundesten Trinkwassergebiete erklärt wurde.

REZUMAT: Indicatori de mediu pentru calitatea apei în râul Cibin (Transilvania, România).

Poluarea apei a devenit o problemă la nivel mondial, iar influența acesteia asupra stării de sănătate a populației umane crește zi de zi. Prezentul studiu are drept scop determinarea gradului de poluare a râului Cibin (România), prin analize fizico-chimice și microbiologice. Probele de apă au fost recoltate din şase locații diferite de-a lungul râului Cibin pe o perioadă de 12 luni. Metodele de analiză utilizate pentru determinarea indicilor de calitate fizico-chimici pentru apă au fost după cum urmează: $\mathrm{O}_{2}$ - ISO 5814/99, pH - SR ISO 10523-97, PO ${ }^{4-}$ KIT Merck, SO ${ }^{4-}$ - PS/LE 17, conductivitate - Sonda, $\mathrm{NH}_{4+}$ - SR ISO 7150-1/2001, $\mathrm{NO}_{3-}$ - SR ISO 7890/2000, $\mathrm{NO}_{2-}$ - SR EN 26777, - ISO 6777/2002, cloruri - SR ISO 9297/2001, CCOCr - SR ISO 6060/96, $\mathrm{CBO}_{5}$ - SR ISO 5815/95, suspensii solide - STAS 6953/81, reziduuri - STAS 9187/95. Probele de apă au fost analizate și din punct de vedere microbiologic, determinânduse: numărul de bacterii mezofile, numărul total de drojdii şi mucegaiuri numărul total de coliformi şi coliformi fecali, Enterococcus și Escherichia coli, în conformitate cu legislaţia și normativele actuale ale României (O. M. 1146/2002). Rezultatele obţinute împart Râul Cibin în clasele I (punctele de prelevare 1, 2 şi 3) şi II (punctele de prelevare 4, 5 şi 6) de calitate. Ţinând cont de faptul că barajul de la Gura Râului reprezintă principala sursă de apă potabilă pentru oraşul Sibiu, prin rezultatele obţinute se poate certifica faptul că apa Râului Cibin prezintă caracteristici optime pentru consumul uman și se declară una dintre cele mai sănătoase ape din România.

\section{INTRODUCTION}

The key to reducing dead zones will be to keep fertilizers on the land and out of the sea. For agricultural systems in general, methods that close the nutrient cycle from soil to crop and back to agricultural soil need to be developed. (Diaz and Rosenberg, 2008)

With the increase in the age of the earth, clean water is becoming more precious as water is being polluted by several man related causes like: rapid population growth, alarming speed of industrialization and deforestation, urbanization, increasing living standards and other wide spheres of other human activities. Ground water, surface water, rivers, sea, lakes, ponds, etc., are finding it more and more difficult to escape from pollution (Shrikanta, 2005; Sandu et al., 2008; Milanović et al., 2011). 
Rivers provide an array of ecosystem goods and services, including biodiversity, attenuation of flood waters, abstraction, recreation, production of power, food and other marketable goods. However, human activities in river catchments over prolonged periods, such as settlement, agriculture and forestry, damaged the freshwater ecosystem and have substantially altered riverine processes (Malmqvist and Rundle, 2002; Gurzău et al., 2010).

Rivers, as ecosystems, have been modified and interfered at different levels. This has developed a requirement for effective management with the ultimate aim to effectively preserve rivers in their natural state (Boon, 1992).

The main sources of water pollution are defined as "any discernable, confined and discrete conveyance, including but not limited to, any pipe, ditch, channel not including agricultural storm water and return flow from irrigated agriculture" (Edwards and Withers, 2008).

Indeed in recent years, efforts to improve water quality were focused on these sources, which have led to an improvement but have also uncovered the previously concealed influence of non-point sources, or diffuse pollution sources, on the aquatic environment (Heathwaite et al., 2005b; Ashbolt, 2004; Sanja et al., 2009).

The Water Framework Directive (WFD - 2000/60/EC) is a European-wide piece of legalization as a response to the degradation of aquatic ecosystems (Carstensen, 2007). This is a significant piece of legislation agreed upon in 2000 and was the result of a 12-year long policy process (Kallis and Butler, 2001). It aims, by 2015, to return waters (fresh, estuaries, coastal and ground) to good ecological and chemical status (Environment Agency, 2006). It is an ambitious goal with an overarching framework approach and is revolutionary with its blend of natural sciences and social elements (Steyaert and Ollivier, 2007).

An interesting approach is that it leaves the translation of aims and objectives of the legislation to member states and local levels (Kallis and Butler, 2001).

World Health Organization (WHO) states that the "infectious diseases caused by pathogenic bacteria, viruses and protozoa or by parasites are the most common and widespread health risk associated with drinking water", frequently as a result of fecal matter from sewage discharges, leaking septic tanks, and runoff from animals (EPA, 2001b; WHO UNICEF, 2004; Balzer et al., 2010).

Potable or drinking water is defined as having acceptable quality in terms of its physical, chemical, and bacteriological characteristics so that it can be safely used for drinking and cooking (Patoli, 2010; Medema et al., 1997; Eleria, 2002).

The rationale of this study is to evaluate the Cibin River, as a water supply for Sibiu citizens, from a sanitary and public health point of view, providing fundamental concepts of water quality control.

\section{MATERIAL AND METHODS}

In the Sibiu Depression, the Cibin meadow has two clearly differentiated sectors: the sector upstream of Sibiu (Gura Râului - Sibiu) in the west-east direction and the sector downstream of Sibiu (Sibiu - Tălmaciu) with a north-west-south-east orientation (Sandu, 1998). The water samples were collected from six different locations along Cibin River (Figs. $1-7)$. 


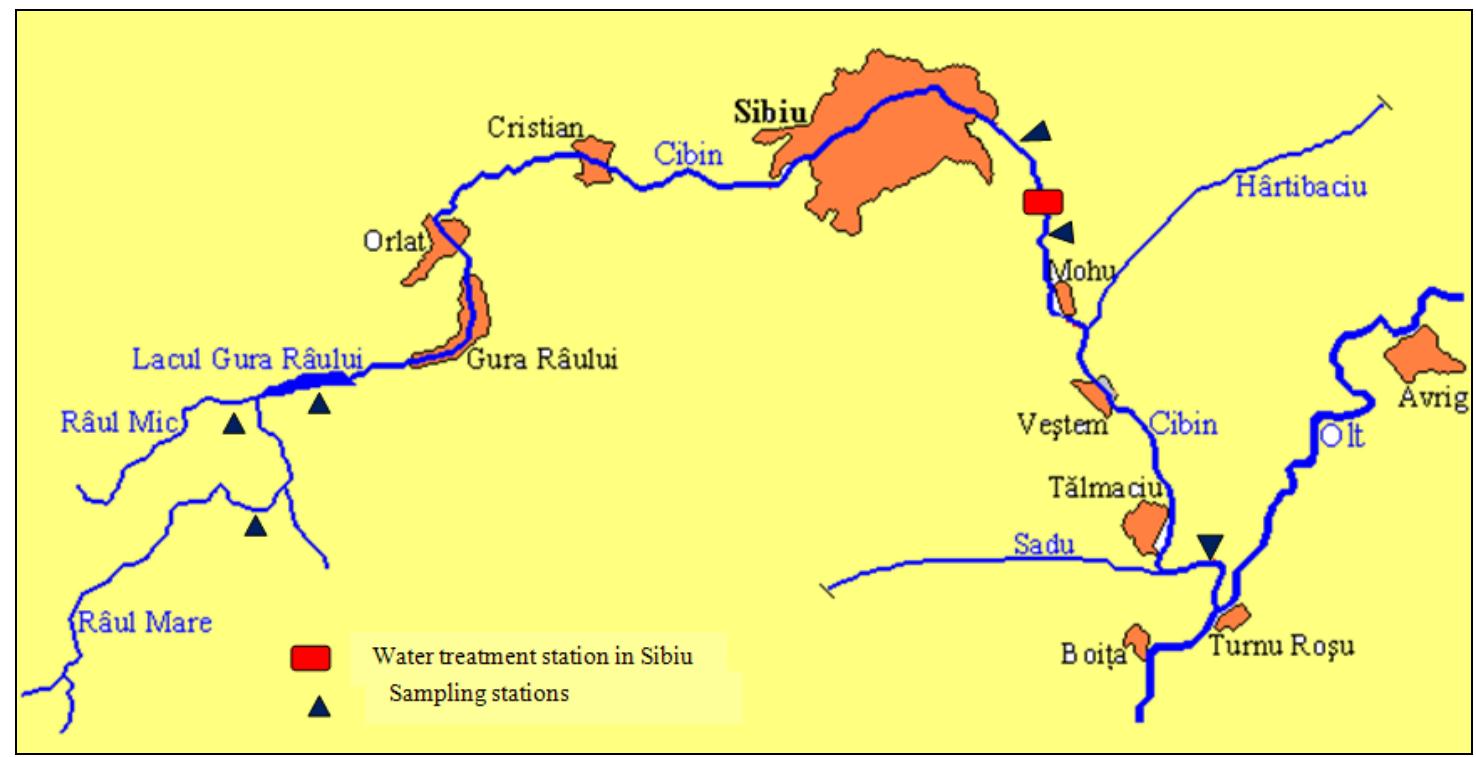

Figure 1: Cibin River in Sibiu Depression with sampling stations.

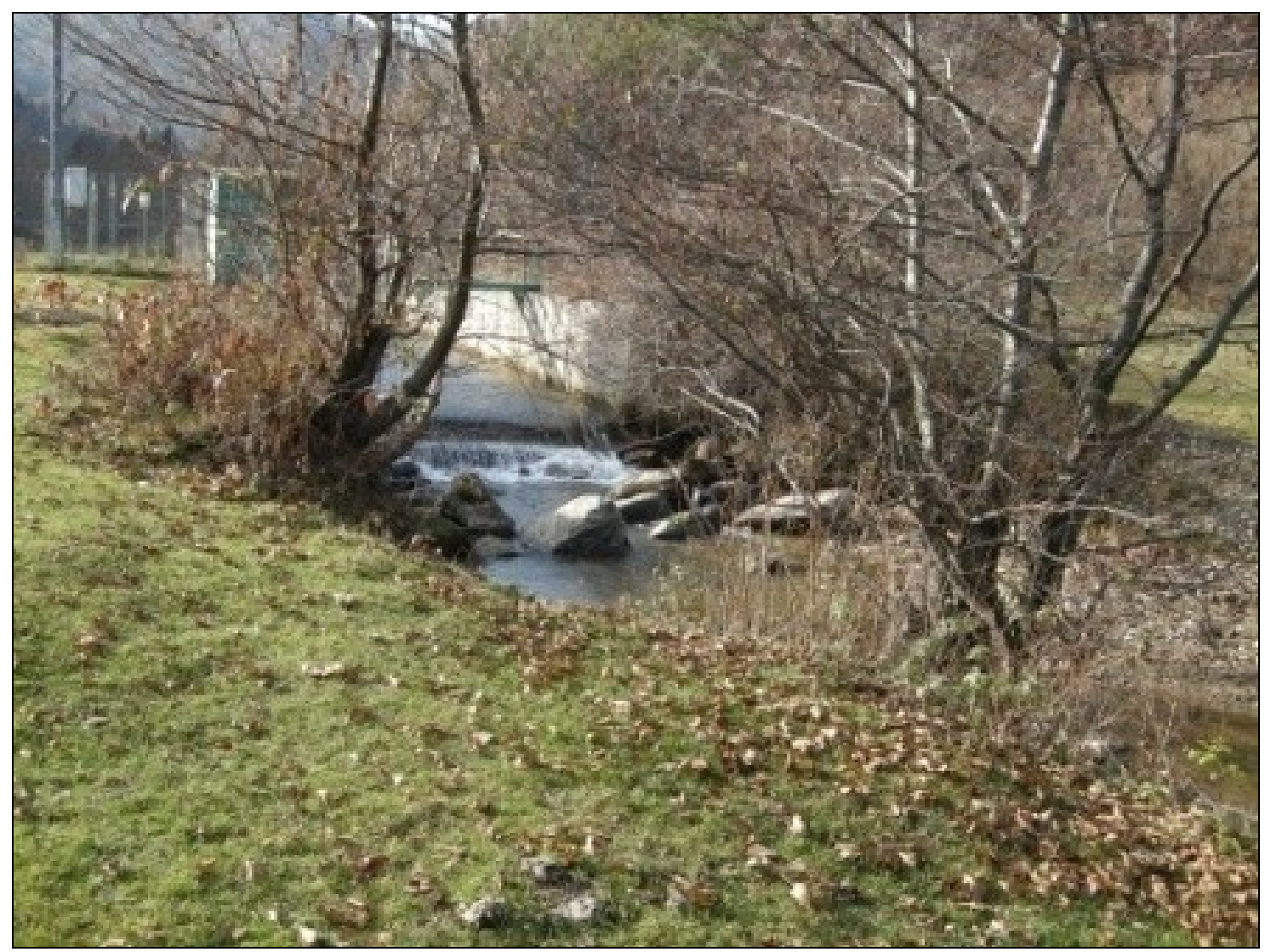

Figure 2: Sampling station 1; Râul Mic, forming together with Râul Mare the Cibin River. 


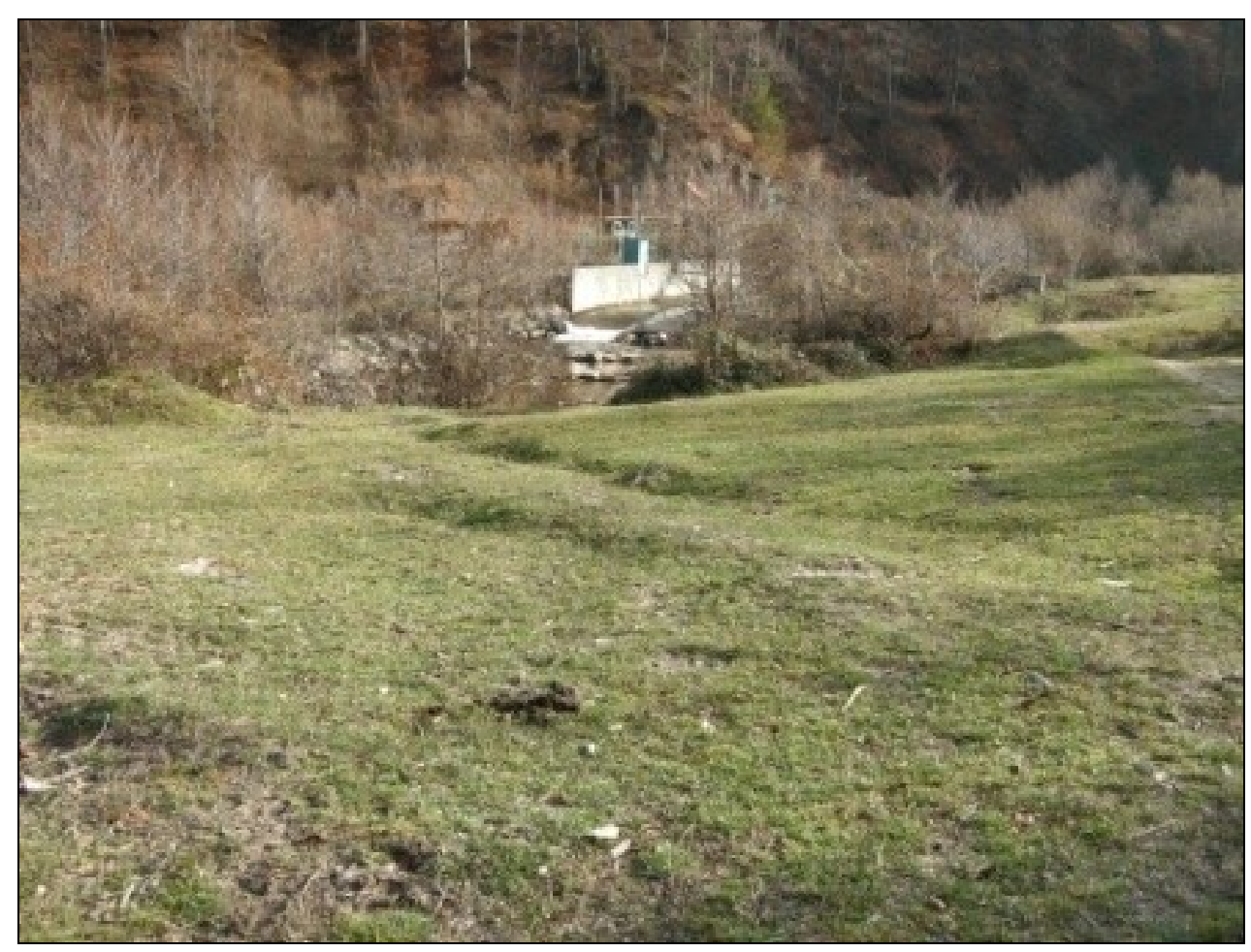

Figure 3: Sampling station 2; Râul Mare, forming together with Râul Mic the Cibin River.

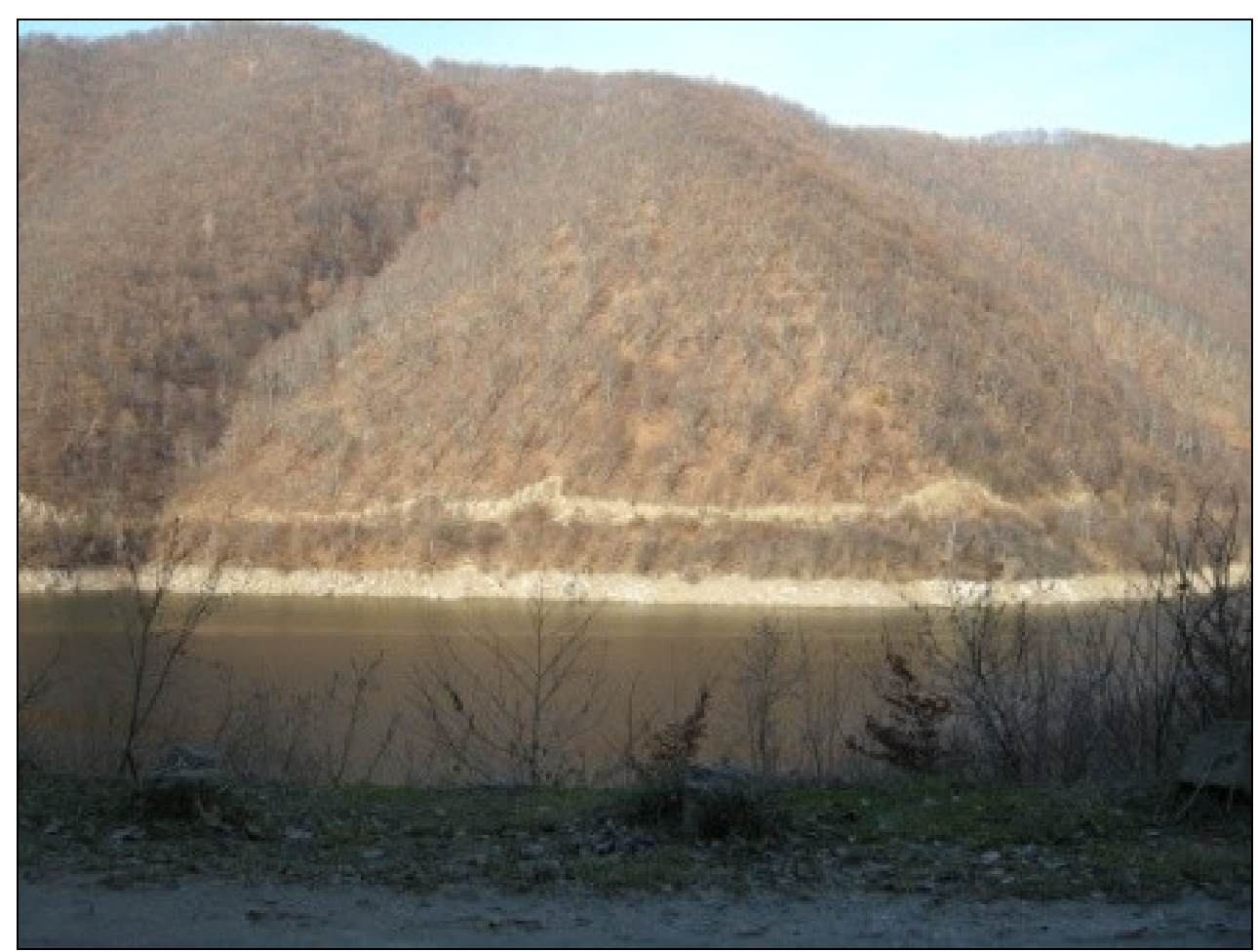

Figure 4: Sampling station 3 at Gura Râului Lake. 


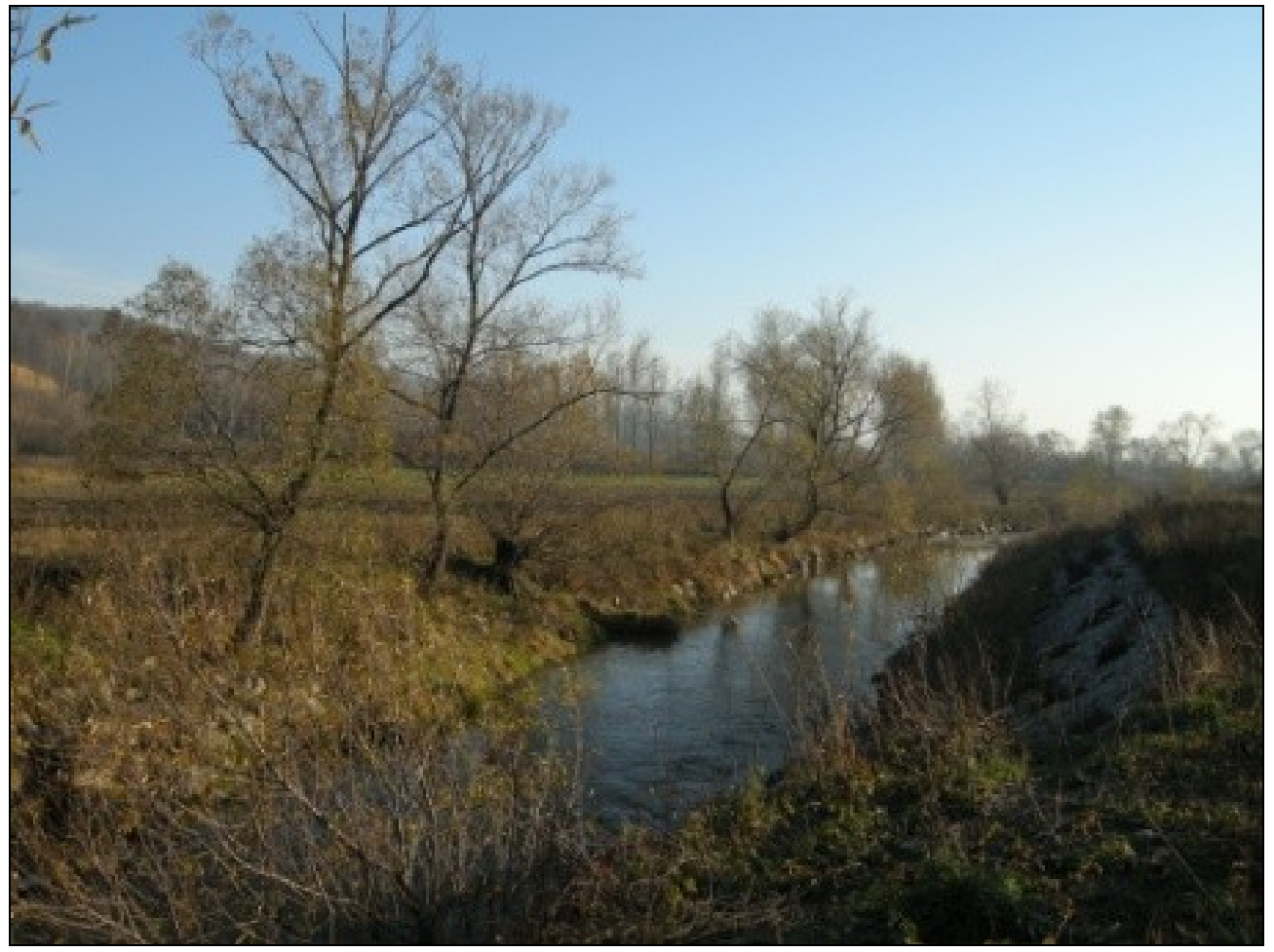

Figure 5: Sampling station 4, downstream Sibiu city, upstream the Water Treatment Station.

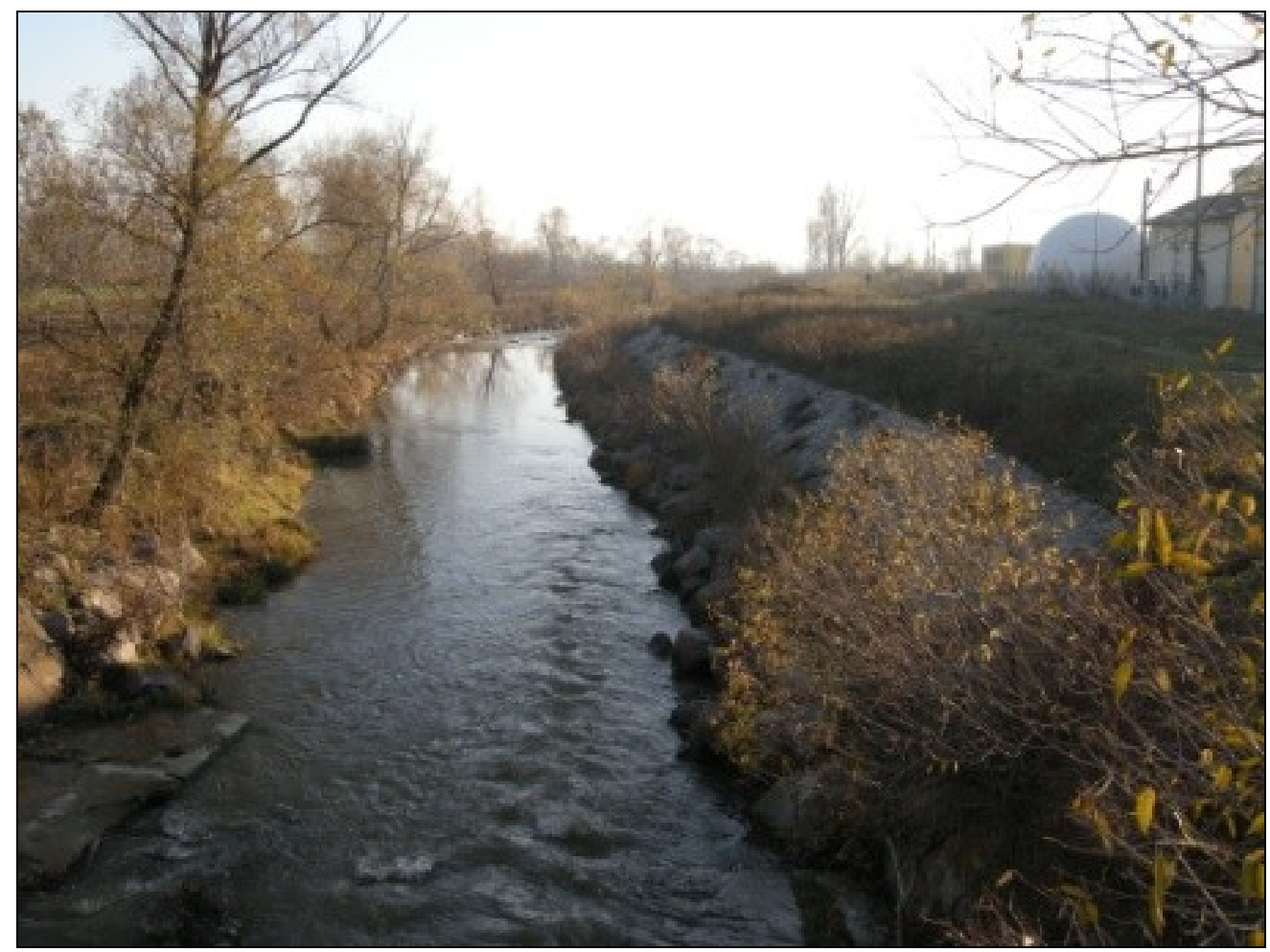

Figure 6: Sampling stations 5, downstream the Water Treatment Plant. 


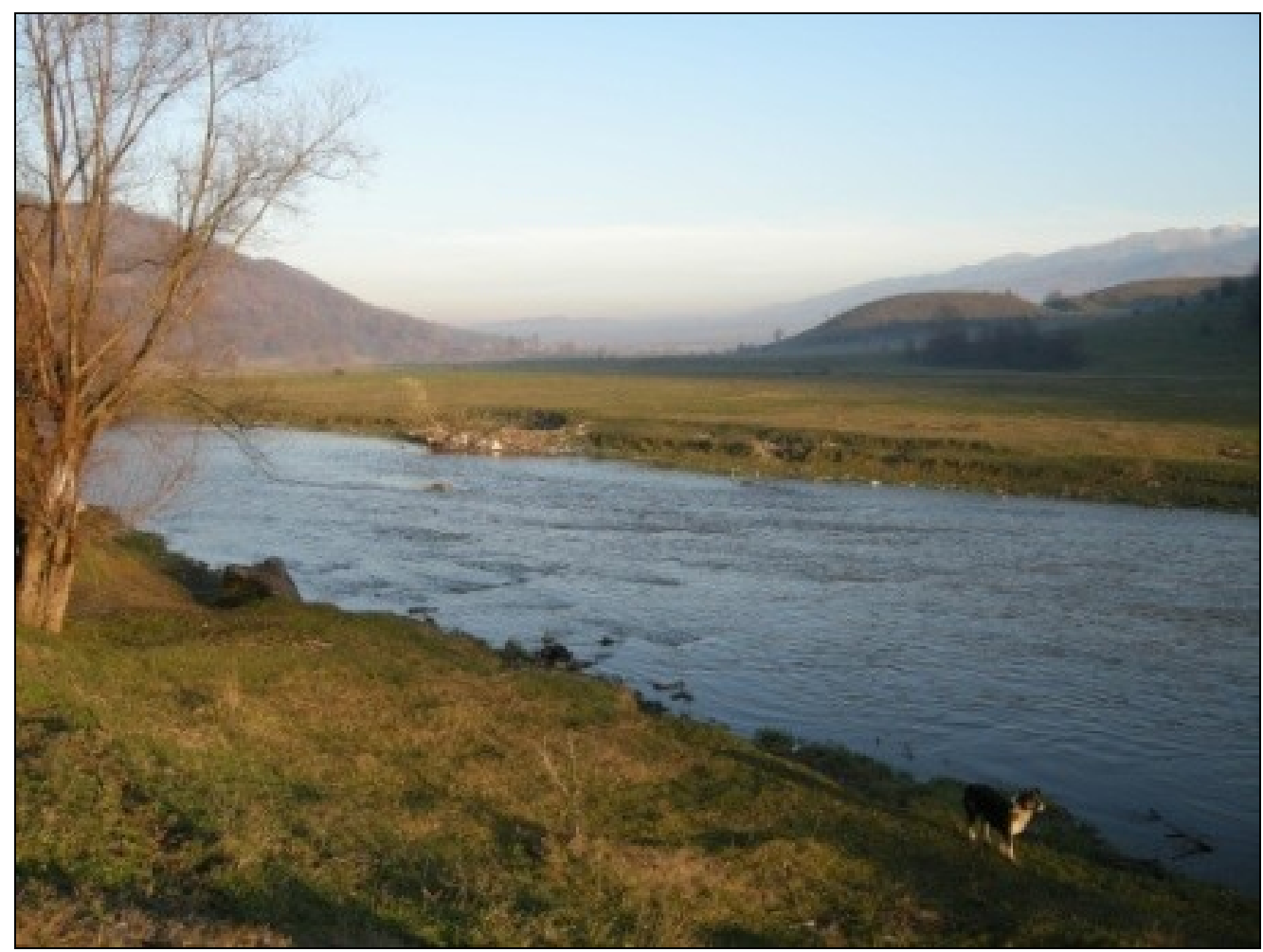

Figure 7: Sampling station 6, $1 \mathrm{~km}$ upstream the Cibin River confluence with Olt River.

The water samples were collected during 2012 period, in three different seasons: spring, summer and autumn. Water samples were collected in sterile bottles for physicalchemical and microbiological tests according to ISO SR EN 17.025/2005 (General requirements for the competence of testing and calibration) and sent to Microbiology and Biotechnology Research Department ("Lucian Blaga" University of Sibiu). During transportation, the samples were kept at $4^{\circ} \mathrm{C}$, otherwise the determination of microorganisms is not relevant.

Analysis methods used to determine the physical-chemical quality indices for water were as follows: $\mathrm{O}_{2}$ - ISO 5814/99, pH - SR ISO 10523-97, $\mathrm{PO}^{4-} \mathrm{KIT}$ Merck, $\mathrm{SO}^{4-}$ - PS/LE 17, conductivity - Sonda, $\mathrm{NH}_{4+}$ - SR ISO 7150-1/2001, $\mathrm{NO}_{3-}$ - SR ISO 7890/2000, $\mathrm{NO}_{2-}-\mathrm{SR}$ EN 26777 - ISO 6777/2002, chlorides - SR ISO 9297/2001, CCOCr - SR ISO 6060/96, $\mathrm{CBO}_{5}$ - SR ISO 5815/95, suspended solids - STAS 6953/81, residues - STAS 9187/95.

Maximum admitted values for potable water quality should be according to the Law no. $458 / 2002$ on potable water quality modified and completed by the Law no. 311/2004.

Categories and technical requirements for surface water, rivers, lakes, natural or artificial, should be according to Order 1146/2002 - Normative regarding the objectives of reference for surface water quality classification.

The water samples from Cibin River were also analyzed from a sanitary and public health point of view, such as: total number of mesophilic bacteria, total number of yeasts and moulds, total coliforms, total fecal coliforms, Enterococcus and Escherichia coli, in accordance with the current Romanian legislation and normative (respectively the Order 1146/2002). 
Total mesophilic bacteria (TMB); Total yeasts and moulds (TYM)

The presence of mezofile (aerobic) bacteria is accomplished by ten-fold dilutions of seeding the water samples. This is accomplished through the incorporation into nutrient solid medium incubated at $22^{\circ} \mathrm{C}$, respectively $37^{\circ} \mathrm{C}$ for $48 \mathrm{~h}$, followed by counting the colonies developed, thereby determining the degree of impurity; method used according to STAS 6222/2004. The medium used for TMB was Nutrient Agar (MERCK, KgaA, Germany) and the medium used for TYM was CZAPEK-DOX Agar (Scharlau Chemie S. A., Barcelona, Spain), sterilized in autoclave at $121^{\circ} \mathrm{C}$.

\section{Total Coliforms (TC)}

The presence of coliforms is accomplished by the presumption (preliminary examination) and confirmed by the confirmatory test (final exam). The presence of coliform bacteria in water indicates the contamination of this river.

The presumptive test for coliform was made in small tubes containing Durham tube placed in the thermostat at $37^{\circ} \mathrm{C} \pm 0.50^{\circ} \mathrm{C}$ for $48 \mathrm{~h}$, according to STAS $3001 / 1991$. After $24 \mathrm{~h}$, the first reading is made for the confirmation of turbidity and gas. It is considered positive vials and test tubes in which the lactose fermentation is highlighted by the presence of gas in the fermentation, no matter how small the amount of gas evolved in the tube. After $48 \mathrm{~h}$, the final reading and passage for the confirmatory test is made for vials and test tubes in which a microbial development (turbidity) with or without gas, with the exception of those who have been confirmed in $24 \mathrm{~h}$.

The confirmation test for coliform was made by inoculating the positive tubes in selective medium Eosin Methylene Blue Agar - EMB (Scharlau Chemie S. A., Barcelona, Spain), incubated at $37^{\circ} \mathrm{C} \pm 0.50^{\circ} \mathrm{C}$ for $24 \mathrm{~h}$. The number of total coliforms was calculated through statistical tables depending on the amount of samples analyzed, taking into account the vials and phials confirmed.

\section{Total fecal coliforms (TFC)}

The presence of coliform bacteria in water indicates recent fecal contamination. The presence of coliforms was made from the vials of presumptive test positive for faecal coliforms bacteria content, through confirmation in Brilliant Green Bile 2\% Broth (Scharlau Chemie S. A., Barcelona, Spain) at $44^{\circ} \mathrm{C} \pm 0.50^{\circ} \mathrm{C}$, incubated for $24 \mathrm{~h}$, according to STAS 3001/1991. Stain environment in yellow (acidification) in conjunction with the production of gas as a result of lactose fermentation in fermentation tubes, indicates the presence of faecal coliforms.

\section{Total enterococci and Escherichia coli}

The procedures employ presumptive test, followed by confirmation, according with STAS 3001/1991. The primary selective agent for enterococcus was Azide Dextrose Broth According to Rothe (Scharlau Chemie S. A., Barcelona, Spain) and for Escherichia coli was Eosin Methylene Blue Agar (Scharlau Chemie S. A., Barcelona, Spain). 


\section{RESULTS AND DISCUSSIONS}

The results of our study have shown a number of interesting points regarding the sanitary parameters and chemical status of Cibin River water quality. These results are comparable to the classification on the classes of water quality, according to the national normative, Order no. 161/2006 - Classification of surface waters in order to establish the ecological status of water bodies: for class I the classification is very good, for class II is good, for class III is moderate, for class IV is bad and for class V is very bad.

The selected water quality concentrations are the results meant to provide information regarding the quality of the Cibin River, each parameter being explained in detail.

Water temperature has important effects on almost every aspect of biodiversity. Temperature influences the amount of oxygen which is dissolved in water, the colder the water is, the higher the amount of oxygen in the water.

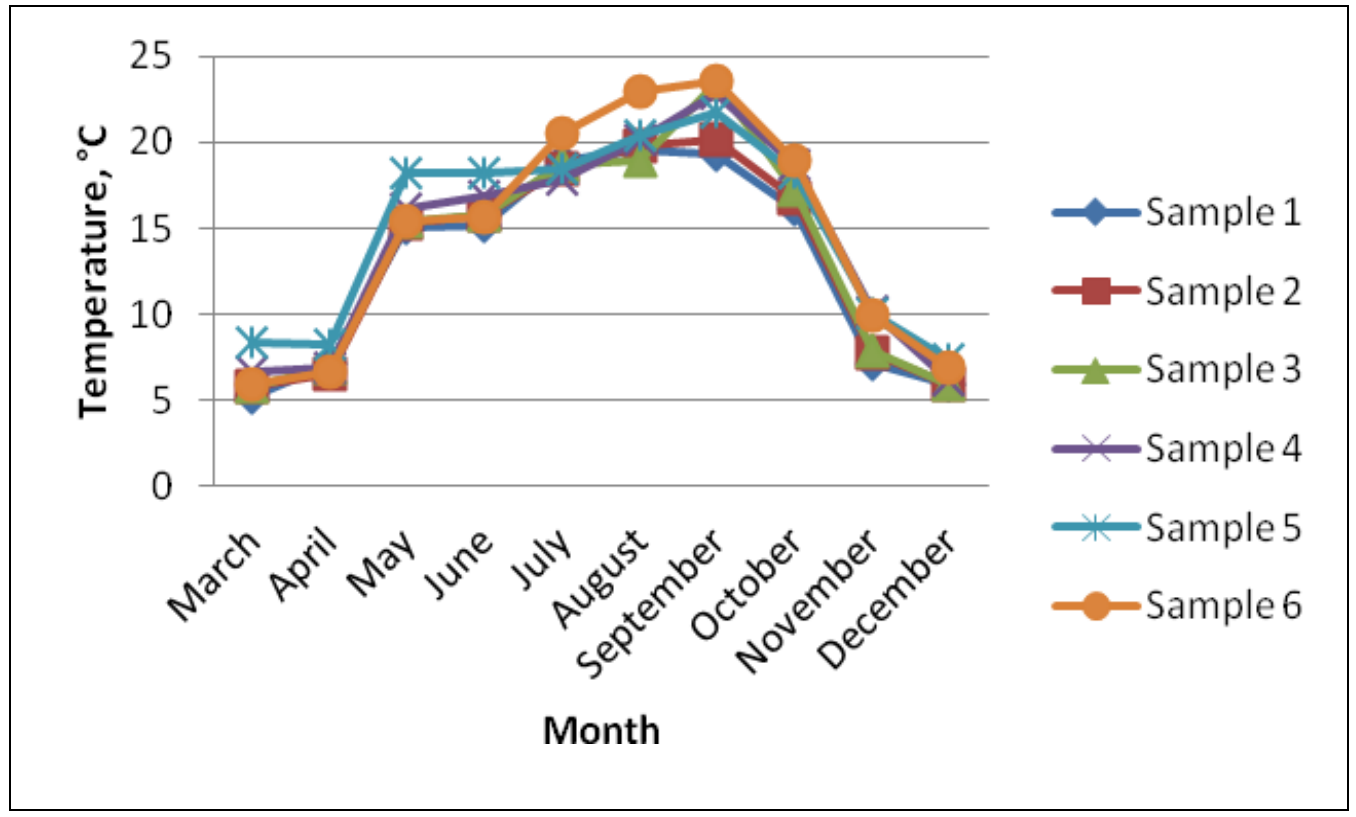

Figure 8: Temperature values during 10 months in the Cibin River monitored points.

As it is shown in figure number 8, Cibin River's temperature oscillates between $5.2^{\circ} \mathrm{C}$ in early spring and $23.5^{\circ} \mathrm{C}$ in autumn. Because the river's sources are located in the mountain area, the temperatures don't exceed $24^{\circ} \mathrm{C}$, not even in the summer time. The river in the outfall has a higher temperature because it reaches open lowland with large opening areas to the sun light. The temperature has a special influence in mesophilic microorganism's development, as shown in figures 9 and 10. They have a positive evolution depending on the determination period and the month when the water samples were collected. It seems that mesophilic bacteria cultivated on nutritive agar at $22^{\circ} \mathrm{C}$ presents maximum values in August in the fifth sample point, those values reaching 10,000 germs $/ \mathrm{ml}$. The most reduced values in this case are found in April in Gura Râului Lake (Fig. 10). Mesophilic bacteria which are developed at $37^{\circ} \mathrm{C}$ (Fig. 10) oscillate from 11 germs $/ \mathrm{ml}$ (at Râul Mic in March and October) to 5,500 germs $/ \mathrm{ml}$ (in August) at the fourth sample point, just upstream the wastewater plant. 


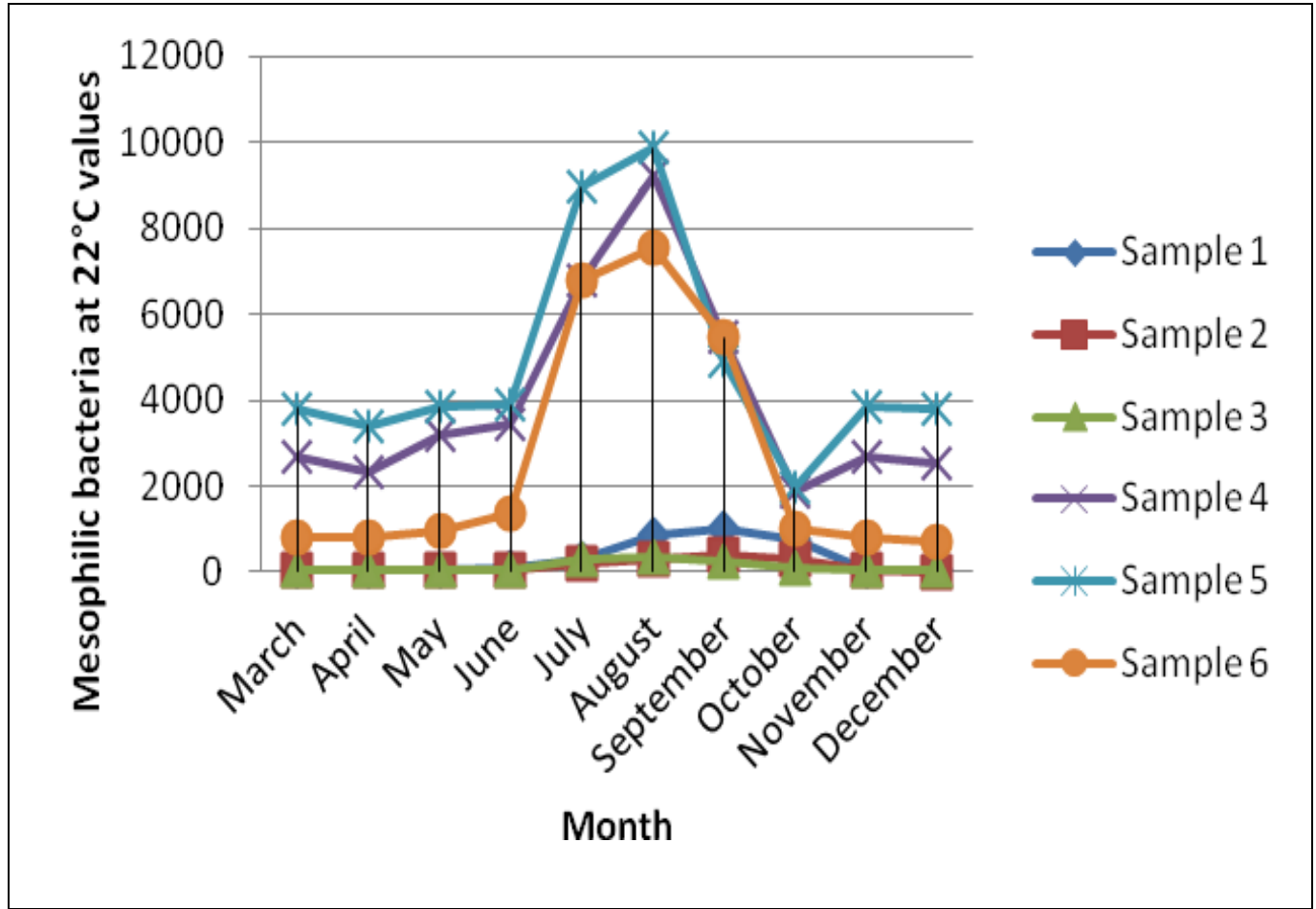

Figure 9: Mesophilic bacteria values at $22^{\circ} \mathrm{C}$ over 10 months in the monitored points of the Cibin River.

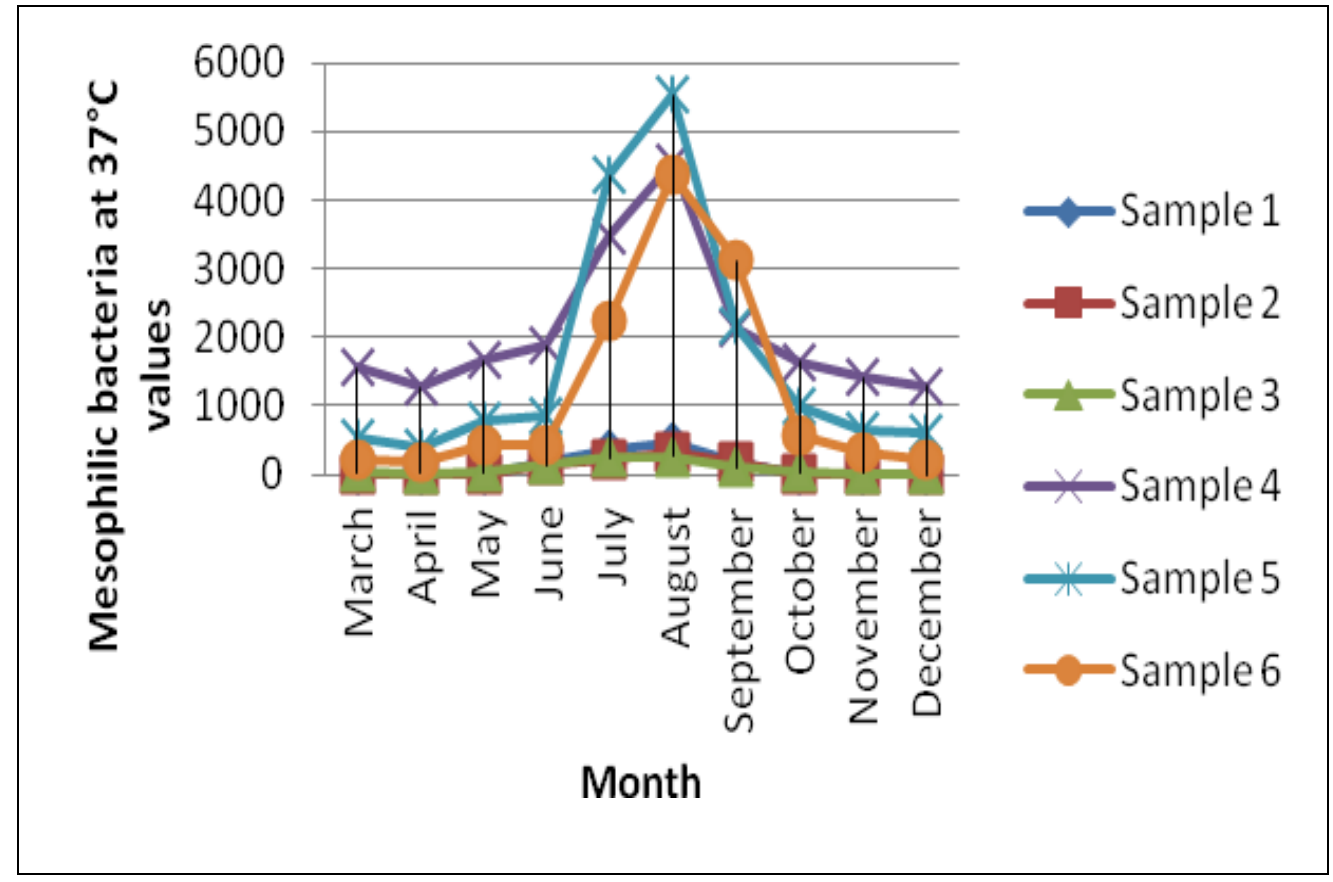

Figure 10: Mesophilic bacteria values at $37^{\circ} \mathrm{C}$ during 10 months in the monitored points of the Cibin River. 
Yeasts and molds were developed in a higher number, up to 4,300 germs $/ \mathrm{ml}$ in August at the wastewater plant entrance. The minimum values were found at the Gura Râului Lake (Fig. 11). The yeast and mold species developed and multiplied at $37^{\circ} \mathrm{C}$ (Fig. 12) were found in a lower number in sampling stations 1,2 and 6 (river sources and $1 \mathrm{~km}$ upstream the confluence with the Olt River).

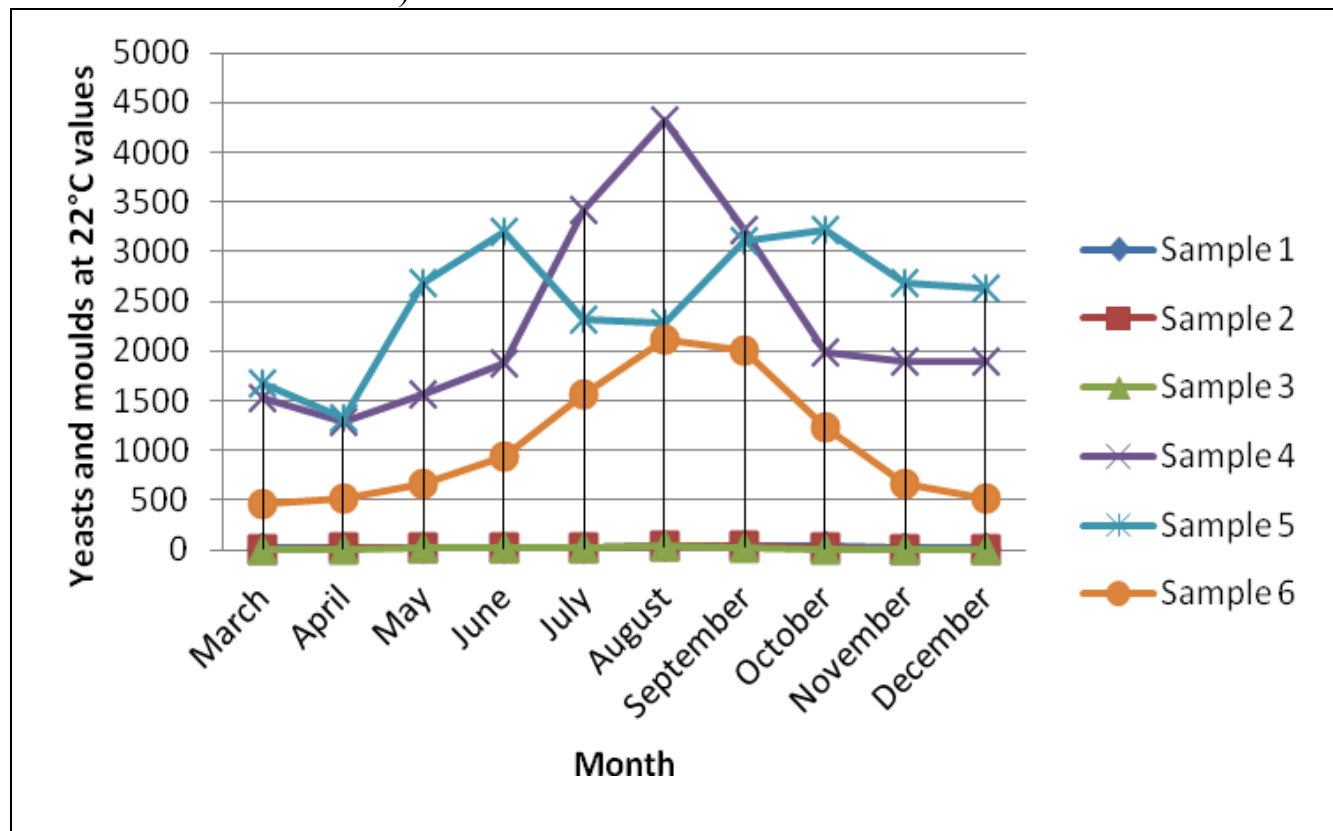

Figure 11: Yeasts and moulds values at $22^{\circ} \mathrm{C}$ during 10 months in the monitored points of the Cibin River.

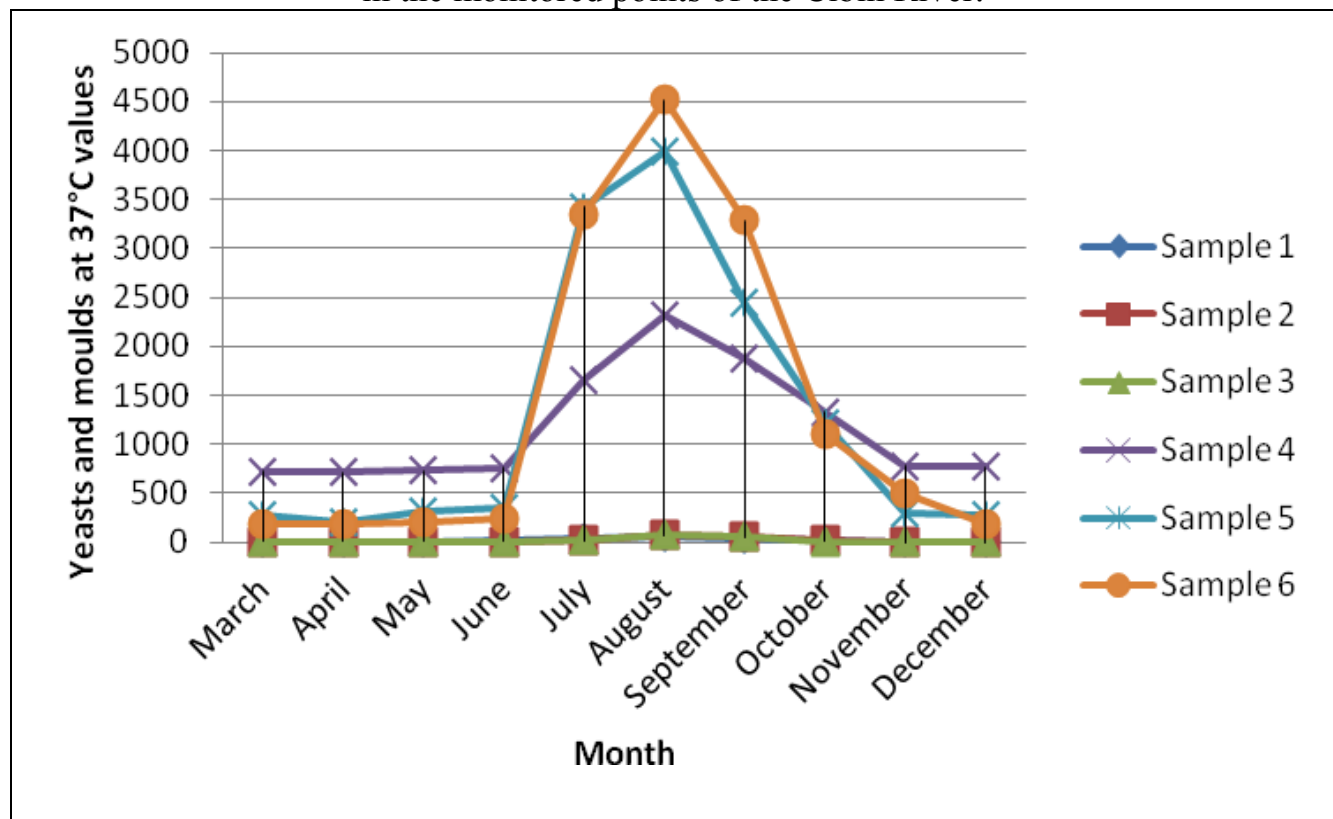

Figure 12: Yeasts and moulds values at $37^{\circ} \mathrm{C}$ during 10 months in the monitored points of the Cibin River. 
River systems are used for disposal of waste, from industries that are near their courses. These effluents from industries have a great deal of influence on the pollution of the water body (bacteria, yeasts and moulds), these effluents can alter the physical, chemical and biological nature of the receiving water body. (Sangodoyin, 1991) Increased industrial activities have led to pollution stress on surface waters, and agricultural and domestic sources are in this situation too. Wastes entering these water bodies are both in solid and liquid forms.

As a result, the water bodies which usually are major receptacles of treated and untreated or partially treated industrial wastes have become highly polluted. The resultant effects of this on public health and the environment are usually high in magnitude. (Osibanjo, 2011)

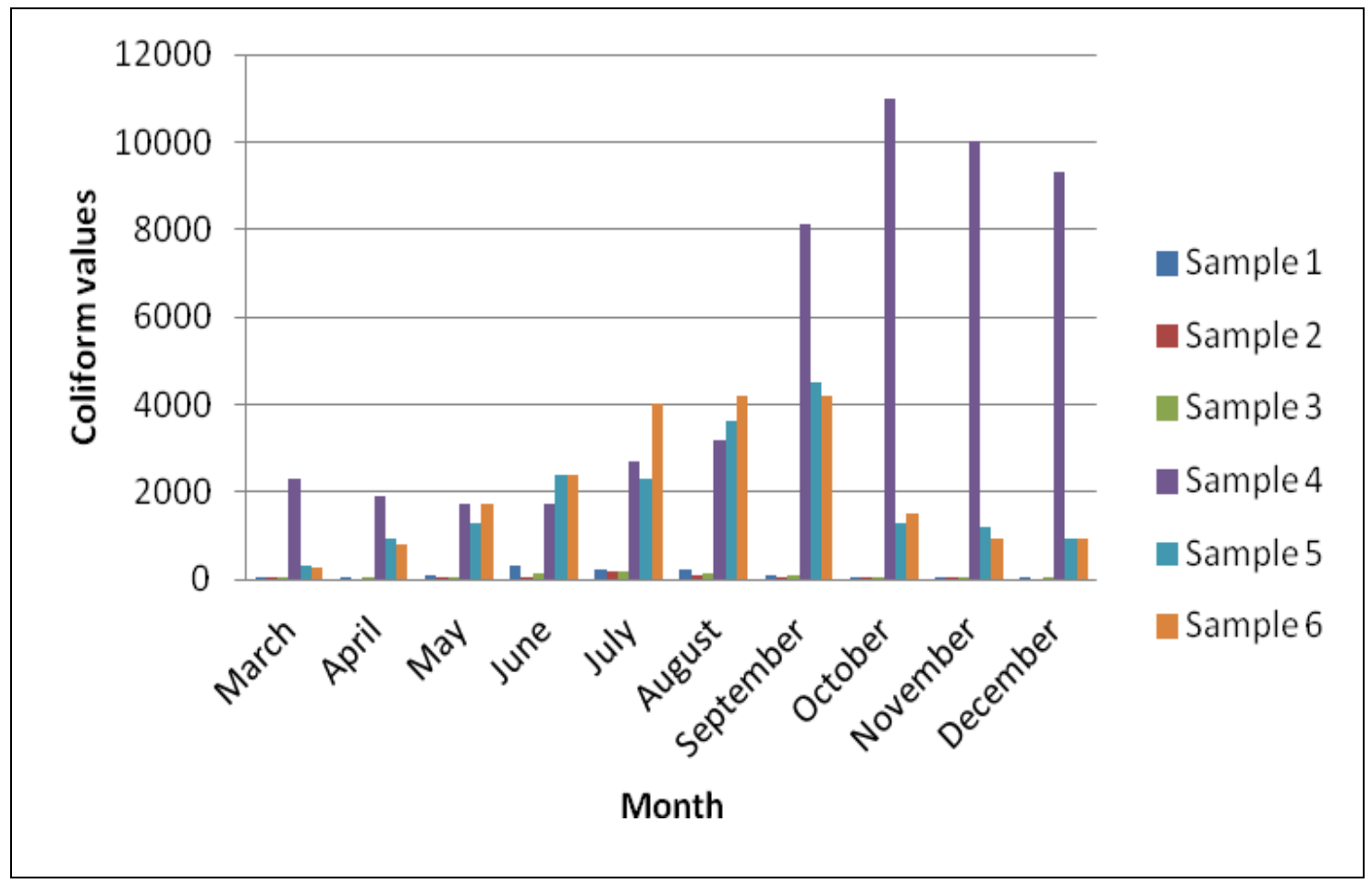

Figure 13: Coliform values over 10 months in the monitored points of the Cibin River.

To determine the likelihood of contamination by organisms, we need to know exactly the coliform concentration. It is well known that the presence of these coliforms, especially of faecal coliforms, will cause diseases such as dysentery, gastroenteritis and hepatitis A. The presence of faecal coliform in a water sample is used to indicate potential contamination. A common source of coliforms and faecal coliform occurs naturally in the digestive tract of warm-blooded animals, where they aid in the digestion of food. The total coliform and faecal coliform amount will indicate if the water is acceptable for drinking, or it is forbidden to drink untreated water from a river or lake. 
The coliforms are the primary water's health indicator, found in different forms as E. coli, faecal coliform, Enterobacter.

In our study, the total coliforms value is between 0 and 10.000 germs $/ 100 \mathrm{~cm}^{3}$ water, but missing from "Râul Mic" Source (Figs. 13 and 14).

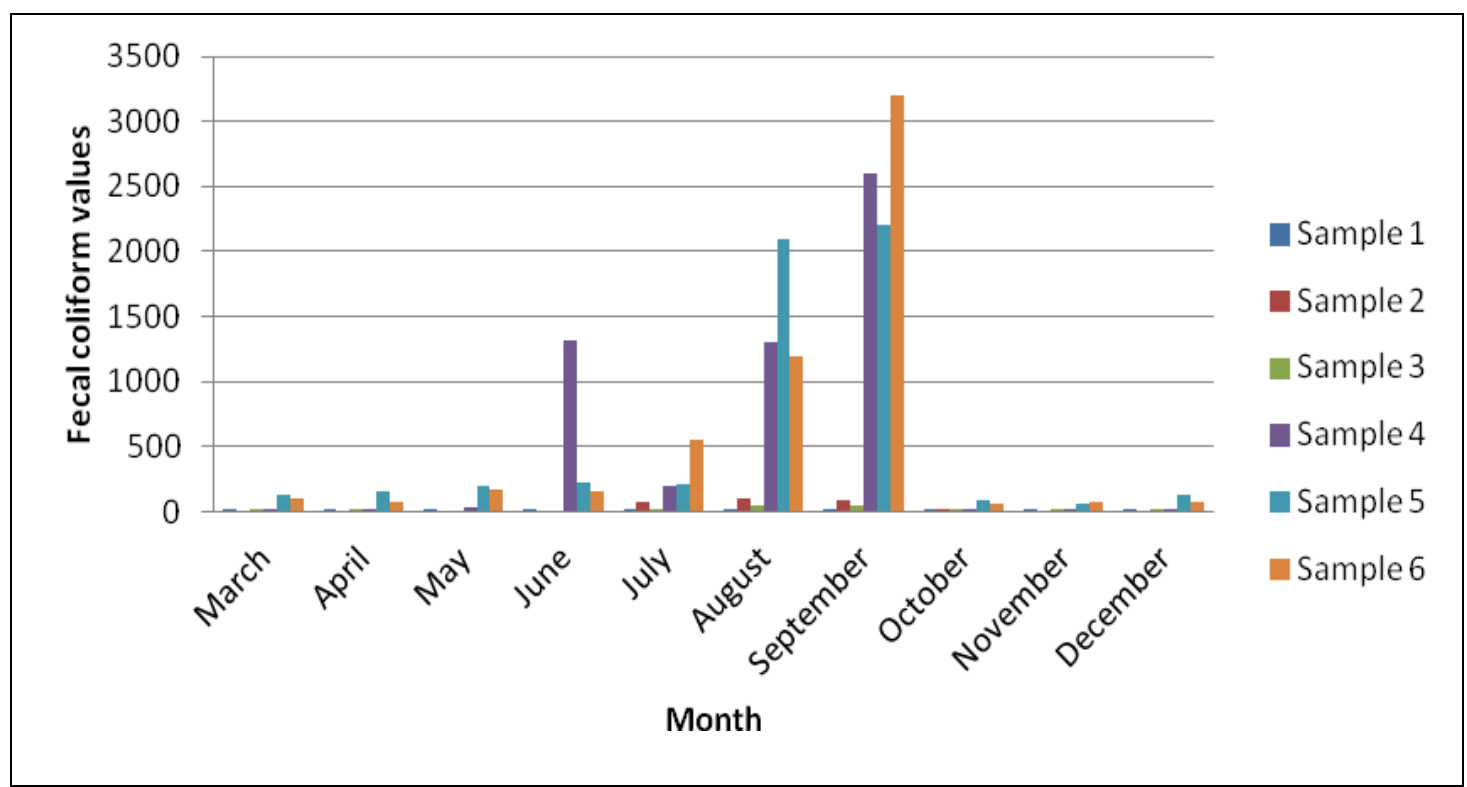

Figure 14: Fecal coliform values during 10 months in the monitored points of the Cibin River.

Escherichia coli and Enterobacter have been the foremost indicators of faecal contamination in water quality monitoring for many decades. Escherichia coli have also been shown to be a significant reservoir of genes coding for antimicrobial drug resistance and therefore is a very useful indicator for resistance in the bacterial communities. (Bucknell, 1997; Patoli, 2010)

The number of coliform bacteria, respectively Escherichia coli, faecal coliform, Enterobacter (Figs. 14, 15 and 16) is increasing substantially in the summer, values reaching between 8.000 and $11.000 / 100 \mathrm{~cm}^{3}$ per sample because in the summer period the tourists camp frequently.

Escherichia coli reaches values of $22 / 100 \mathrm{~cm}^{3}$ per sample at the source zone and increases to 600 at the outfall. There is a lower number of coliforms, so the water from Cibin River has a good quality.

The water from the Gura Râului Lake has very low number of coliform bacteria, bacteria which do not exceed $170 / 100 \mathrm{~cm}^{3}$ per sample, water which is considered as being safe for drinking. 


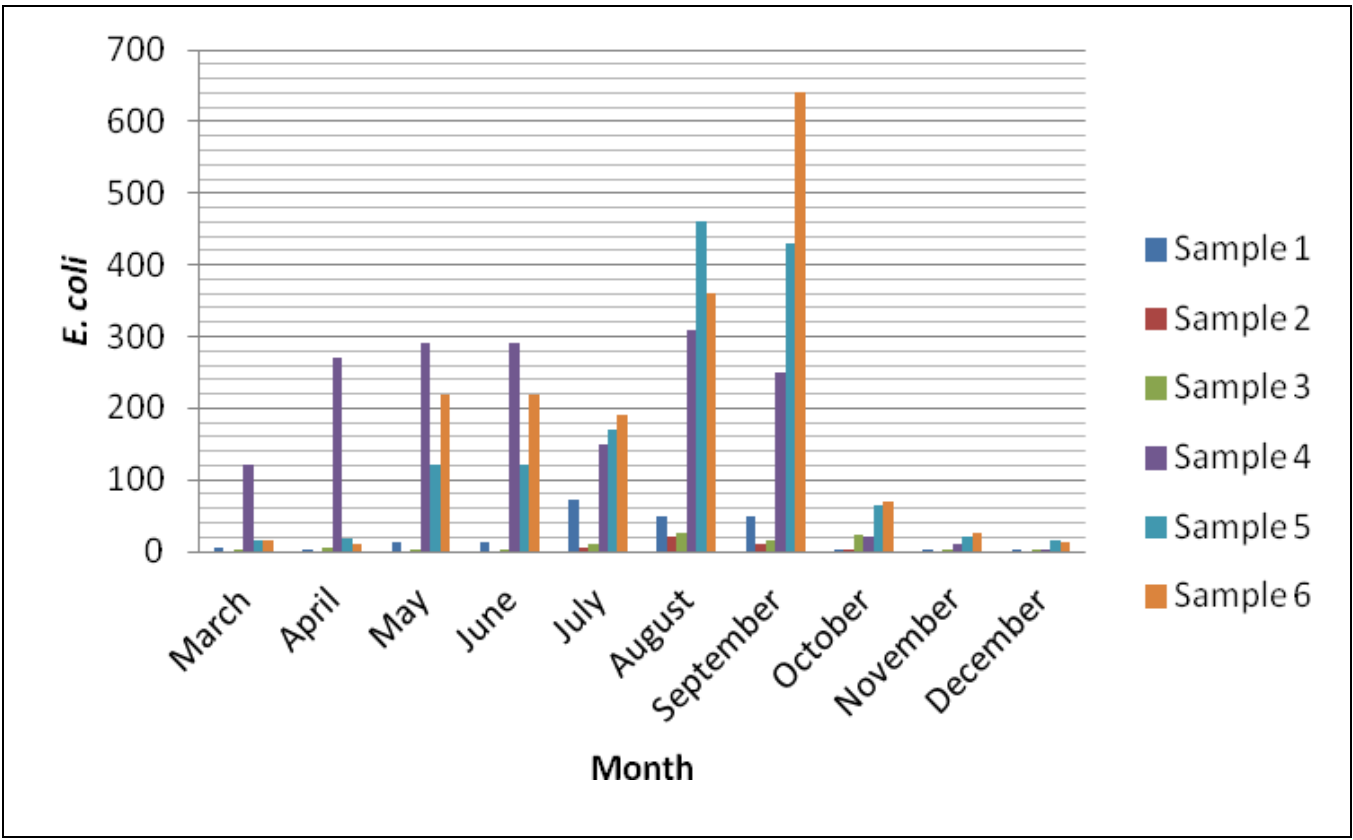

Figure 15: Escherichia coli values during 10 months in the monitored points of the Cibin River.

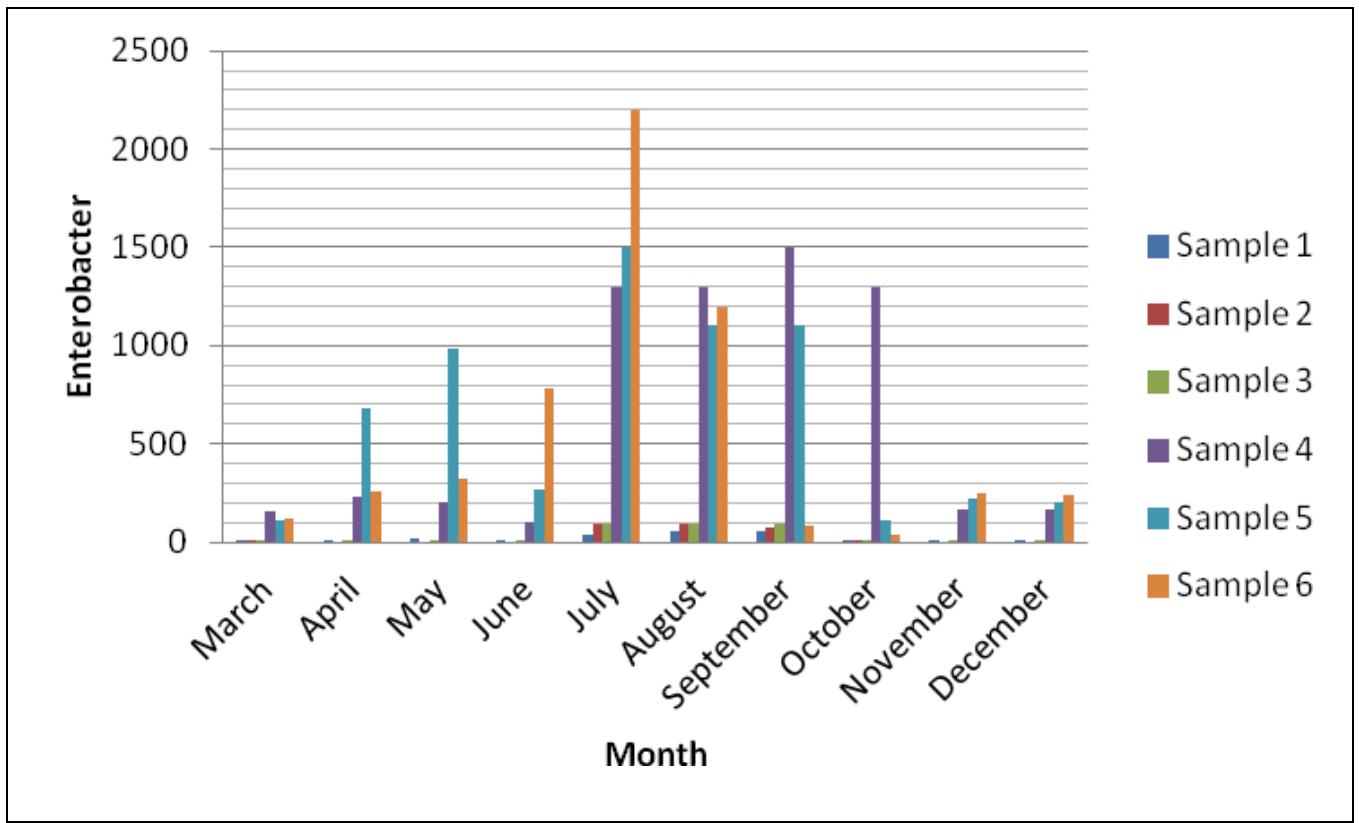

Figure 16: Enterobacter values during 10 months in the monitored points of the Cibin River.

$\mathrm{pH}$ is an important factor that determines the suitability of water for various purposes, including toxicity to animals and plants (Venkatesharaju, 2010).

The $\mathrm{pH}$ is around 7, being neutral in most of the water samples.

Figure number 17 shows minimum values reaching 6.4 and maximum to 7.66 . 


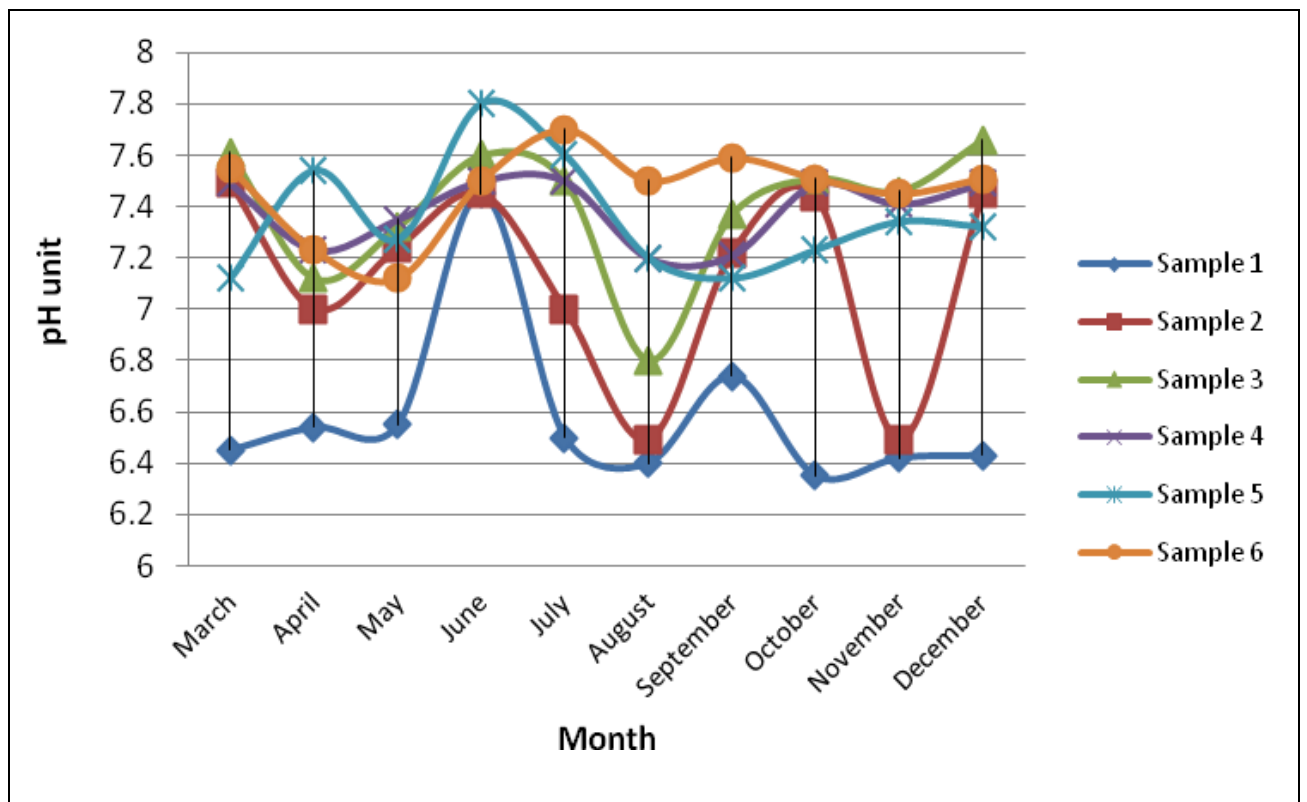

Figure 17: $\mathrm{pH}$ values during 10 months in the monitored points of the Cibin River.

As shown in figure number 18 , we can see that sulphates show constant values throughout the period monitored for the first 3 points of the Cibin River.

The values increase by 3-4 times in the extra urban areas of the Cibin River, downstream and upstream of the water treatment plant, upstream the Olt River.

The determined values do not constitute a major factor of degradation; the results classify Cibin River in the 1st class of quality.

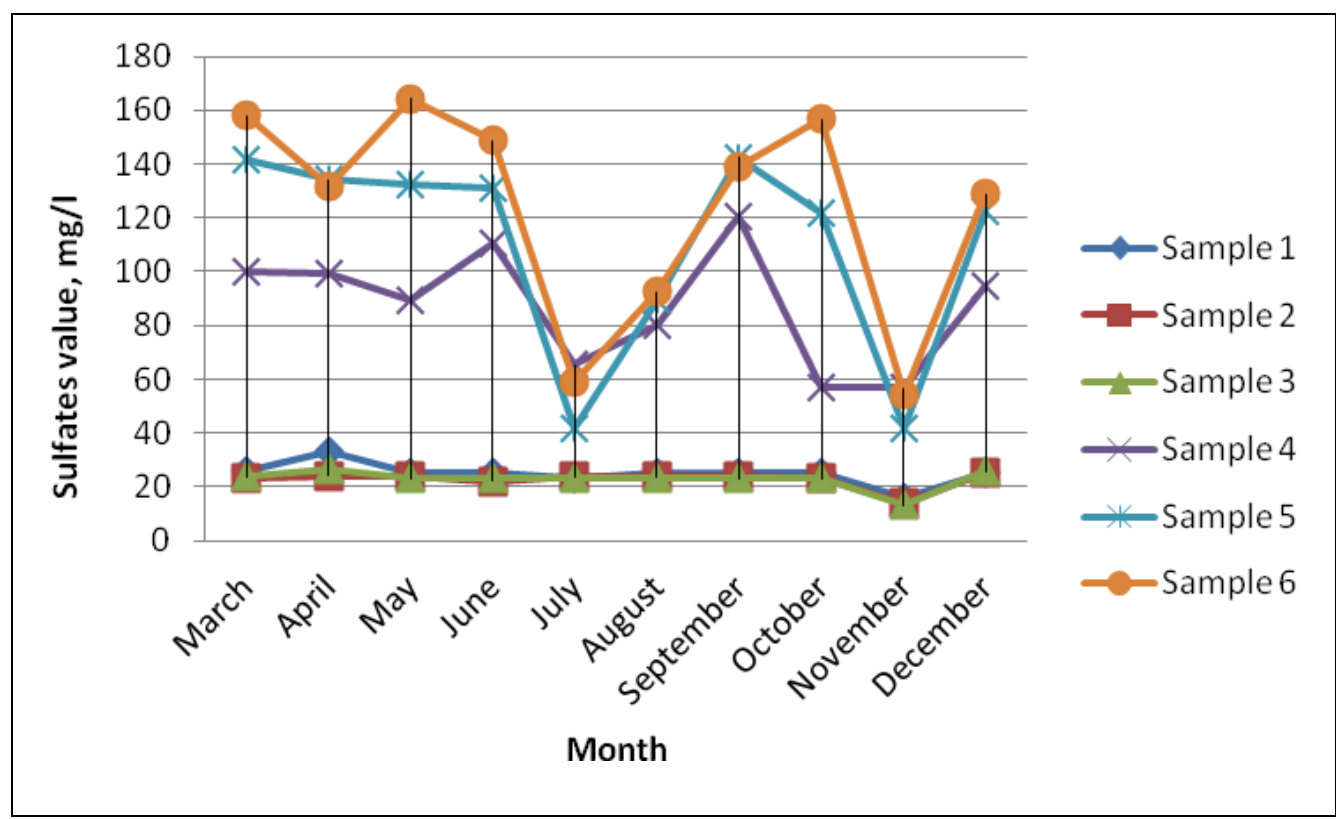

Figure 18: Sulphates values during 10 months in the monitored points of the Cibin River. 
Conductivity is a measure of the ability of an aqueous solution to carry an electric current. This ability depends on the presence of ions, on their total concentration, mobility and valence and on the temperature of measurement (Venkatesharaju, 2010).

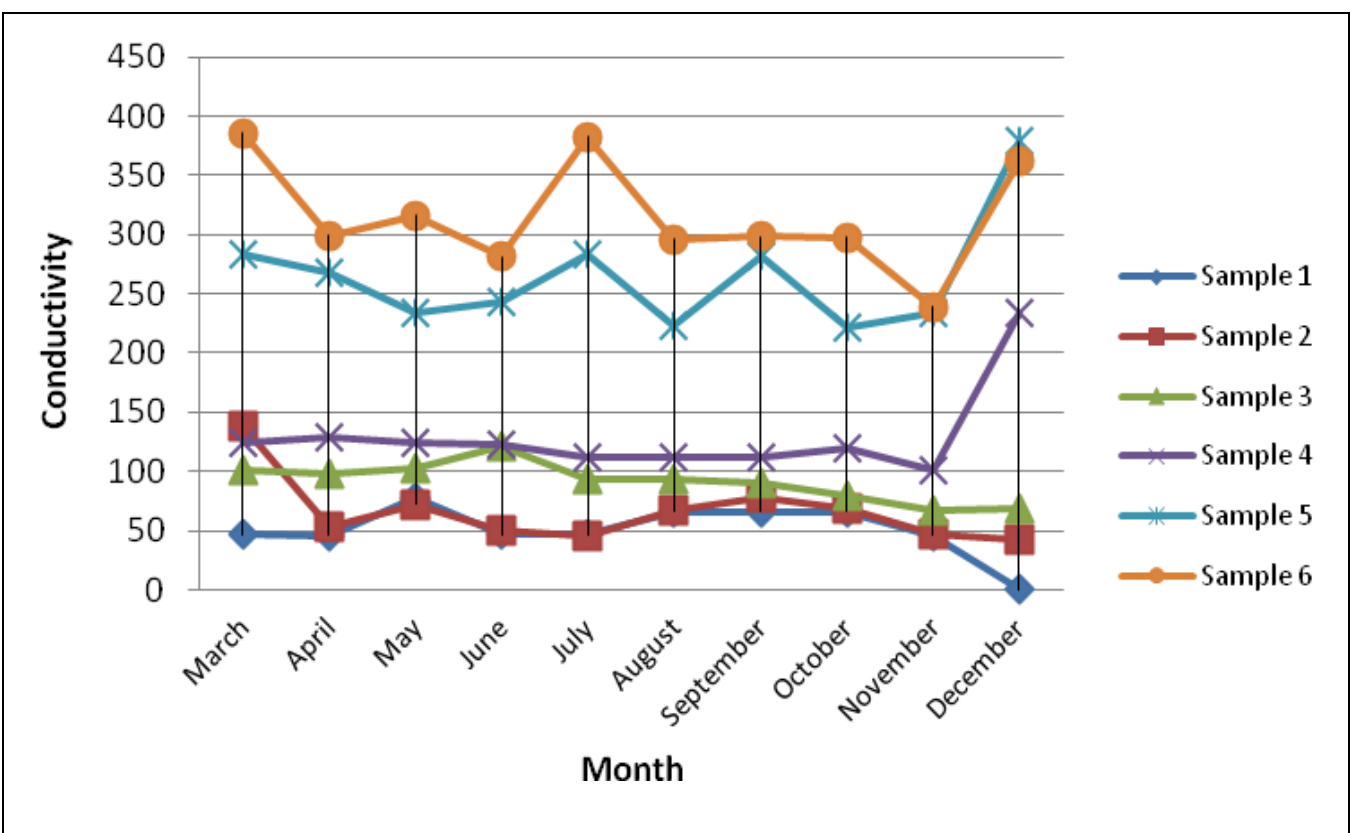

Figure 19: Conductivity values during 10 months in the monitored points of the Cibin River.

Figure number 19 shows the conductivity values from a minimum of $38 \mu \mathrm{S} / \mathrm{cm}$ to $387 \mu \mathrm{S} / \mathrm{cm}$ maximum, at the river sources area and at the confluence area with the Olt River.

Conductivity increases with the passage of the river through inhabited areas, being directly proportional to the fixed residue presented in figure number 20 .

The suspended solids are the solids remaining in a water sample filtered through a 1.2 $\mu \mathrm{m}$ filter. According to the World Health Organization (WHO, 1997), the compounds and elements remaining after filtration are commonly calcium, magnesium, sodium, potassium, carbonate, bicarbonate, chloride, sulphate, silica and nitrate-n. A high amount of suspended solids affects the taste and odor of water, knowing that at levels above $300 \mathrm{mg} / 1 \mathrm{become}$ noticeable to consumers. If the suspended solid increases, the river water becomes increasingly unacceptable.

Residues existence can reduce the clarity of the water, it can degrade the aquatic habitats and can increase the temperature, negative effects that shouldn't happen, and that are decreasing the photosynthesis activity and will have a higher mortality for aquatic animals. 


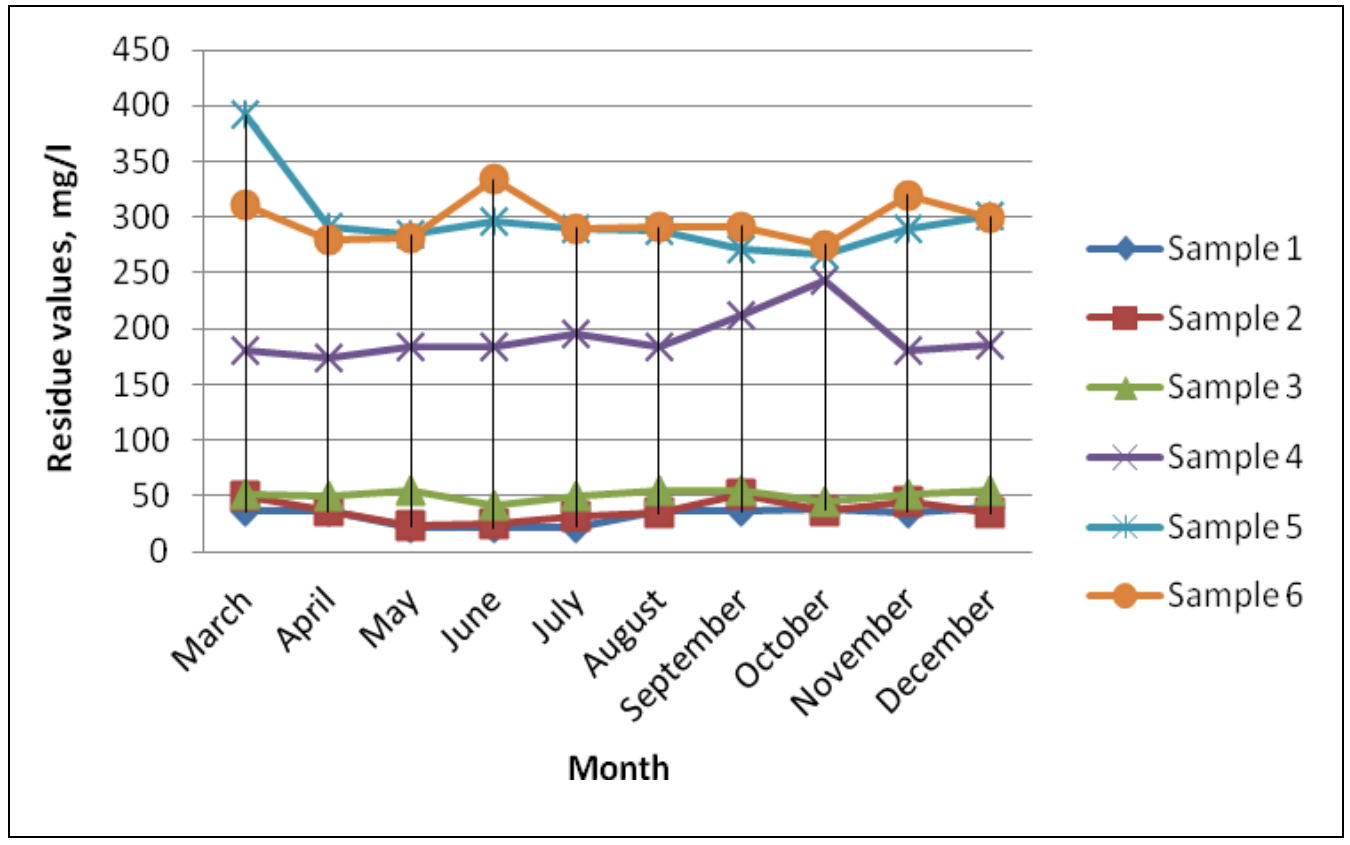

Figure 20: Residue values during 10 months in the monitored points of the Cibin River.

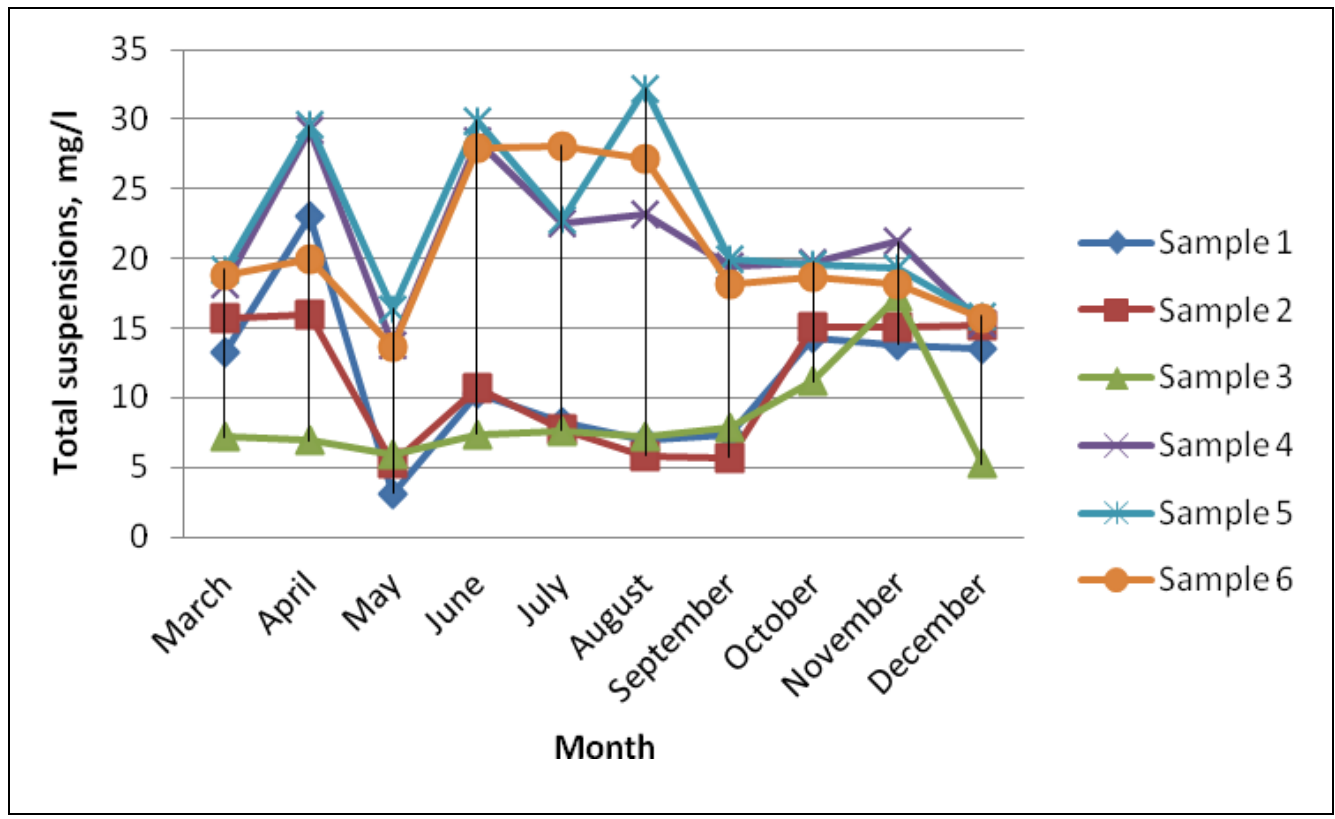

Figure 21: Suspended solid values during 10 months in the monitored points of the Cibin River. 
A special characteristic of the Cibin River is the fact that the suspensions are found in low amounts ranging between 5.3 and $29.2 \mathrm{mg} / \mathrm{l}$, which strengthens the decision of the Cibin River insertion in 1st class of quality.

The variability of the suspension is an indication of banks hygiene both for the source and of the points of collection, the variations being among $30-40 \%$.

Once the snow melts, in the spring, a series of natural elements engage in the sources, this is why they appear in a higher volume in the first two monitoring months (March and April). The values registered in October, November and December is the consequences of human pollution.

During the winter period, with low irradiance conditions, primary nutrients including also $\mathrm{NH}_{4}$ accumulate due to continuing inputs and low phytoplankton nutrient uptake activity. In spring period, increases in seasonal irradiance create conditions for phytoplankton growth and $\mathrm{NH}_{4}$ concentrations decrease due to dilution by spring runoff (Peterson et al., 1985).

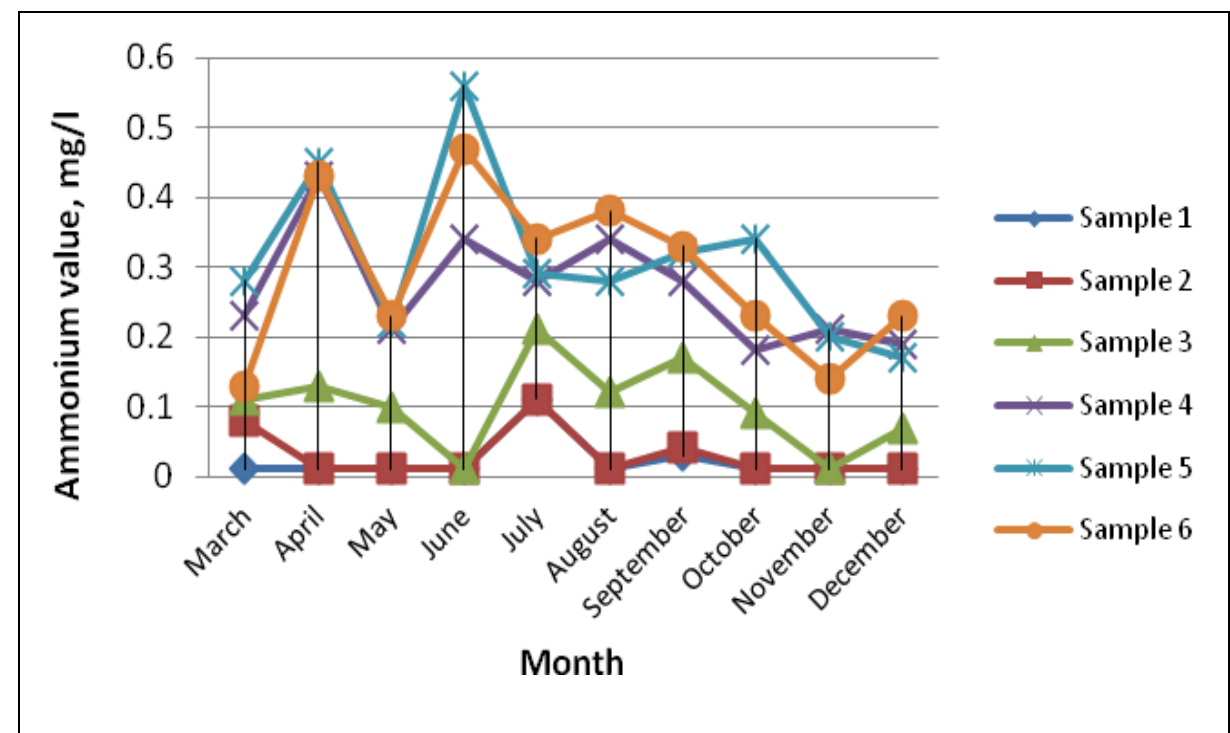

Figure 22: Ammonium values during 10 months in the monitored points of the Cibin River.

Nitrate and nitrites determinations are important in assessing the potential biological productivity of surface waters. Increasing concentration of phosphorus and nitrogen compounds in lakes and reservoirs leads to eutrophication. Phosphates and nitrates can be present due to agricultural runoff during rainy season and used as nutrients by algae and other aquatic plants. (Venkatesharaju, 2010) 


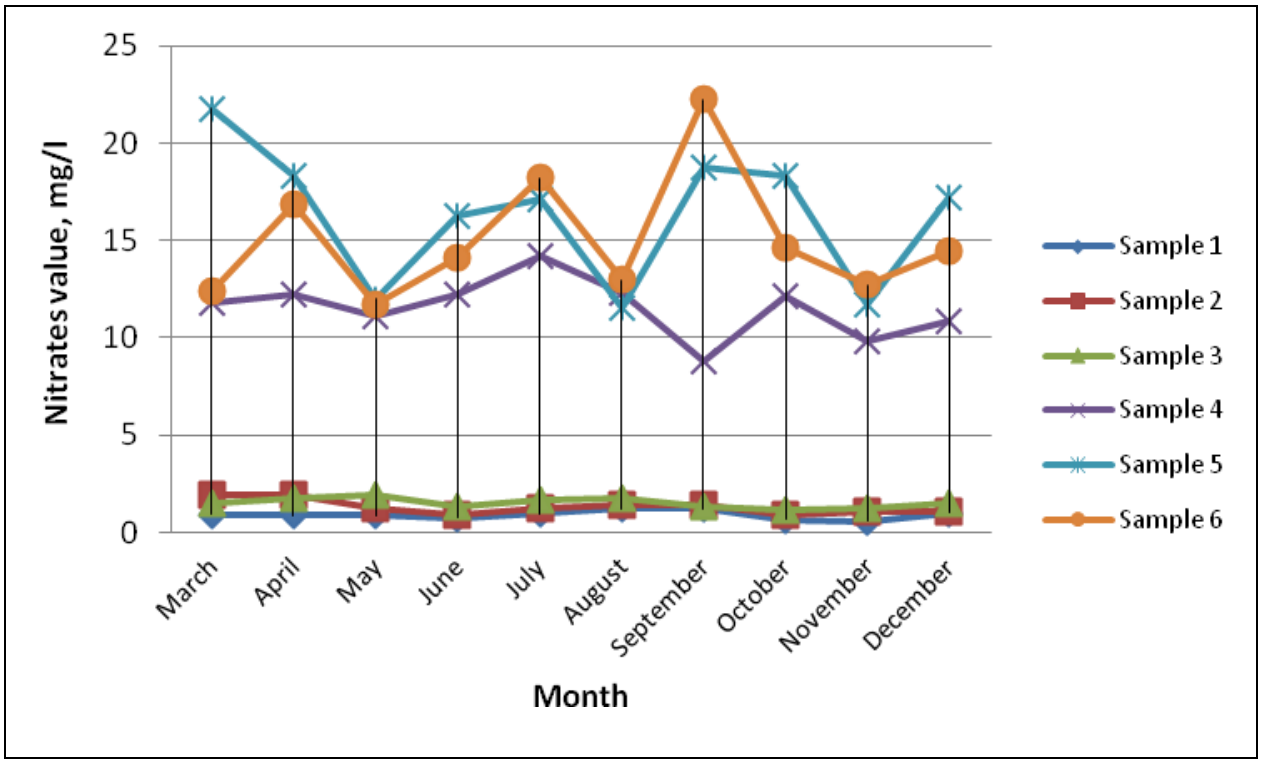

Figure 23: Nitrates values during 10 months in the monitored points of the Cibin River.

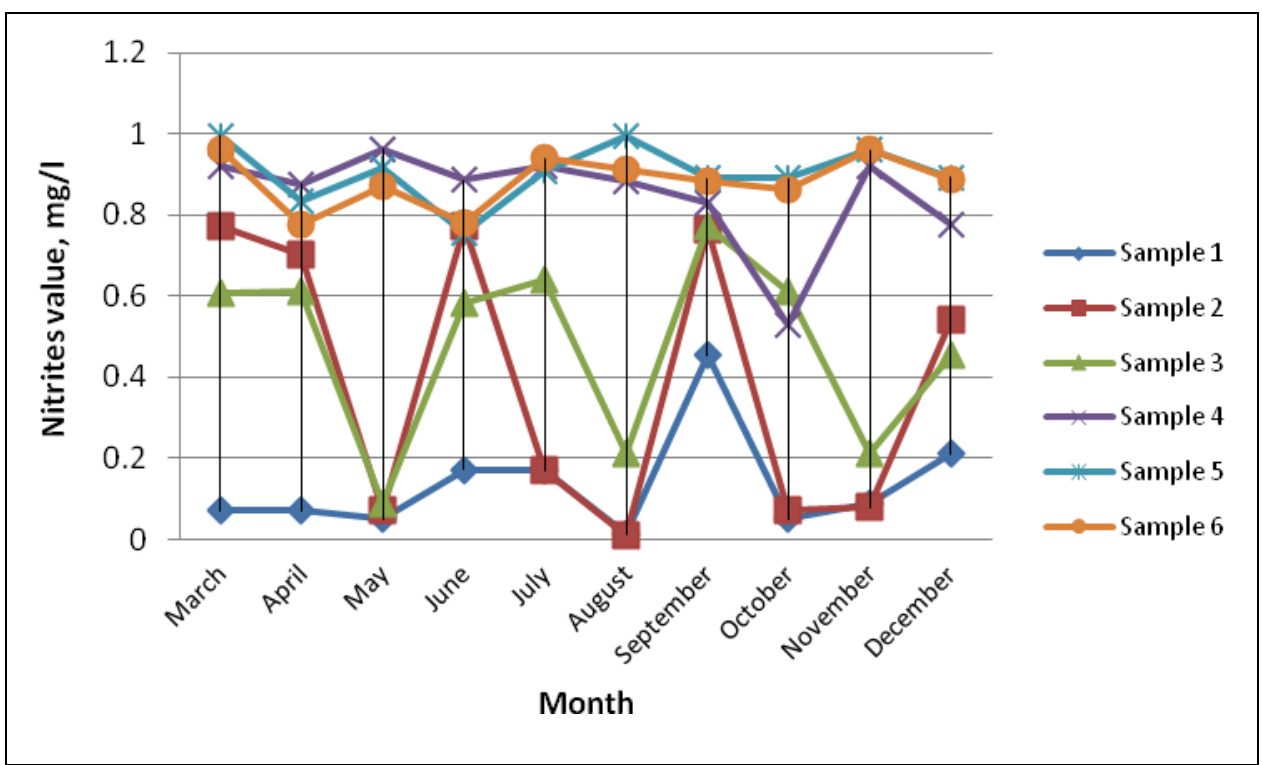

Figure 24: Nitrites values during 10 months in the monitored points of the Cibin River.

After the monitoring of Cibin River it seems like nitrite and ammonia values classify this river in first quality class (values even 100 times lower than the maximum admitted limits). 
On the other hand, the nitrites exceed the maximum admitted limits for the first quality class in downstream zones of wastewater treatment plant and also at the confluence area of Cibin River with Olt River. The nitrate concentration varies in these two points, being influenced by the spills from the rural zones. These values are higher in the summer time; this portion of river being in the second quality class. The minimum values are below $1 \mathrm{mg} / 1$ to 2 $\mathrm{mg} / \mathrm{l}$ in the source zones and dam reservoir and they become higher than $8 \mathrm{mg} / 1$ to $23 \mathrm{mg} / \mathrm{l}$ at the final formation of the river.

Chlorides occur naturally in all types of waters. High concentrations of chlorides are considered to be the indicators of pollution due to organic wastes of animal or industrial origin. Chlorides are troublesome in irrigation water and also harmful to aquatic life. (Rajkumar, 2004).

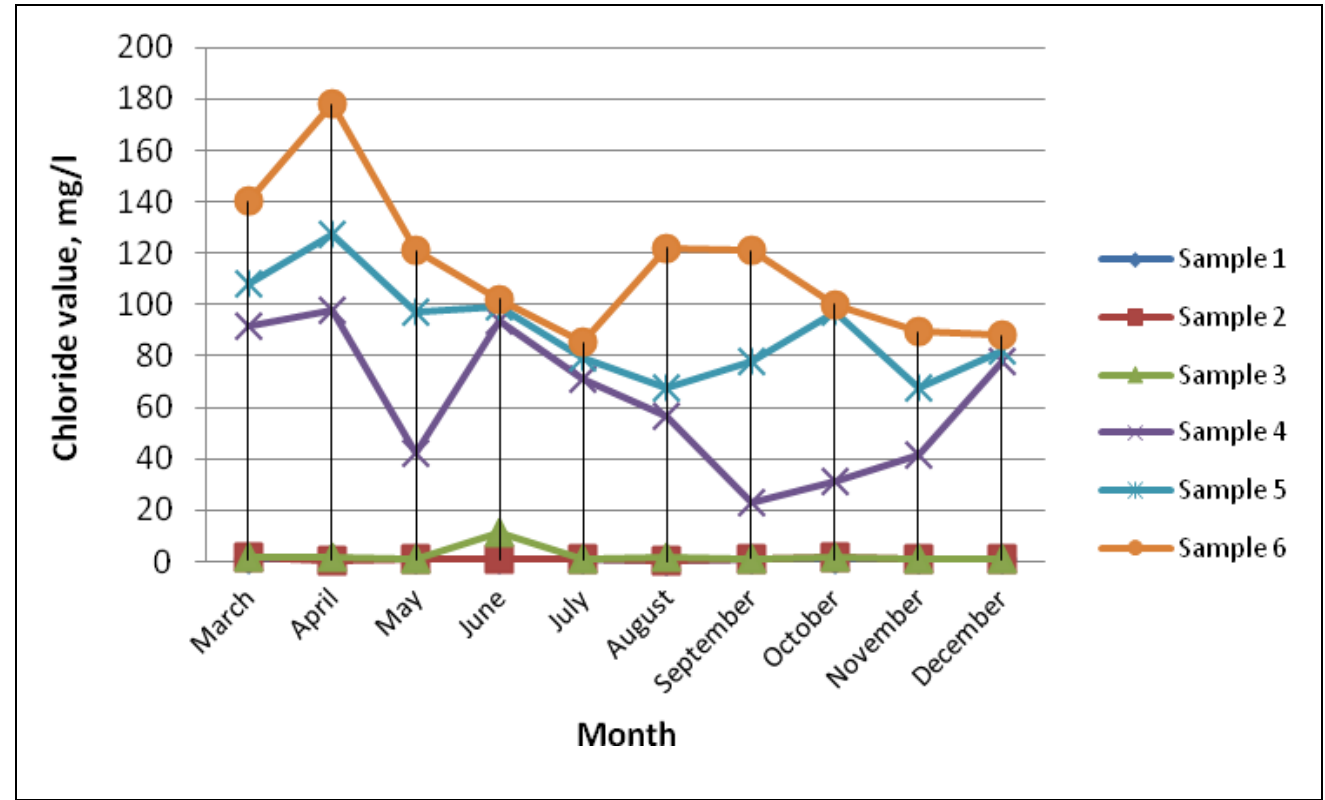

Figure 25: Chloride values during 10 months in the monitored points of the Cibin River.

The chlorates values are below $250 \mathrm{mg} / 1$ (Fig. 25), proving once again the efficiency of the antipollution implementation programs of Cibin River but also the fact that the river receives water at good standard parameters from the wastewater treatment plant.

Oxidation processes, which take place into the river's water, provide the necessary energy for the biochemical processes which sustain the aquatic life. The water quality is represented in a certain way by the existing and consumed quantity of $\mathrm{O}_{2}$ in water.

Biochemical oxygen demand is an important indicator of the consumption of oxygen, necessary quantity, of its decomposition and mineralization of organic matter in aerobic conditions.

From this point of view, the value of monitored waters framed the first three sections of River Cibin (sources and the lake) in the first class of quality, and the last three sections in the second class of quality. 


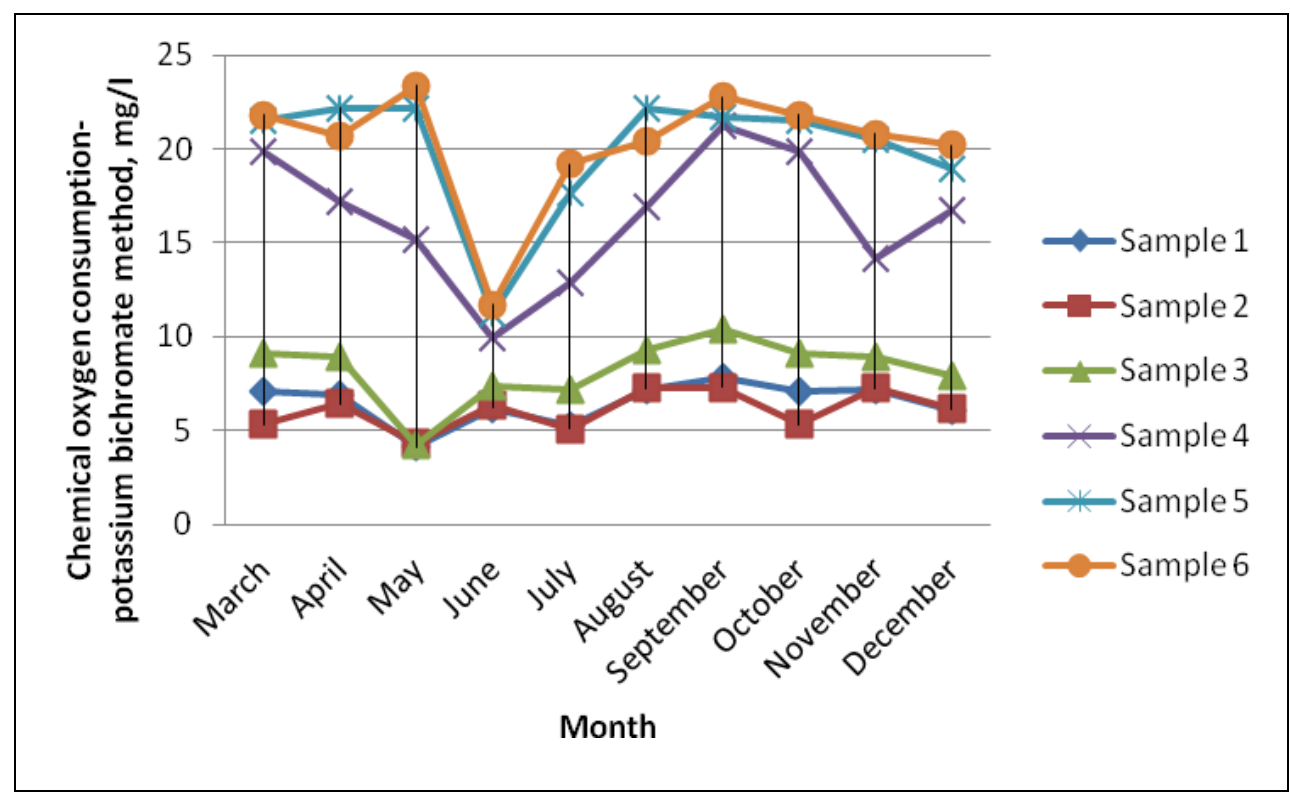

Figure 26: CCOCr values during 10 months in the monitored points of the Cibin River.

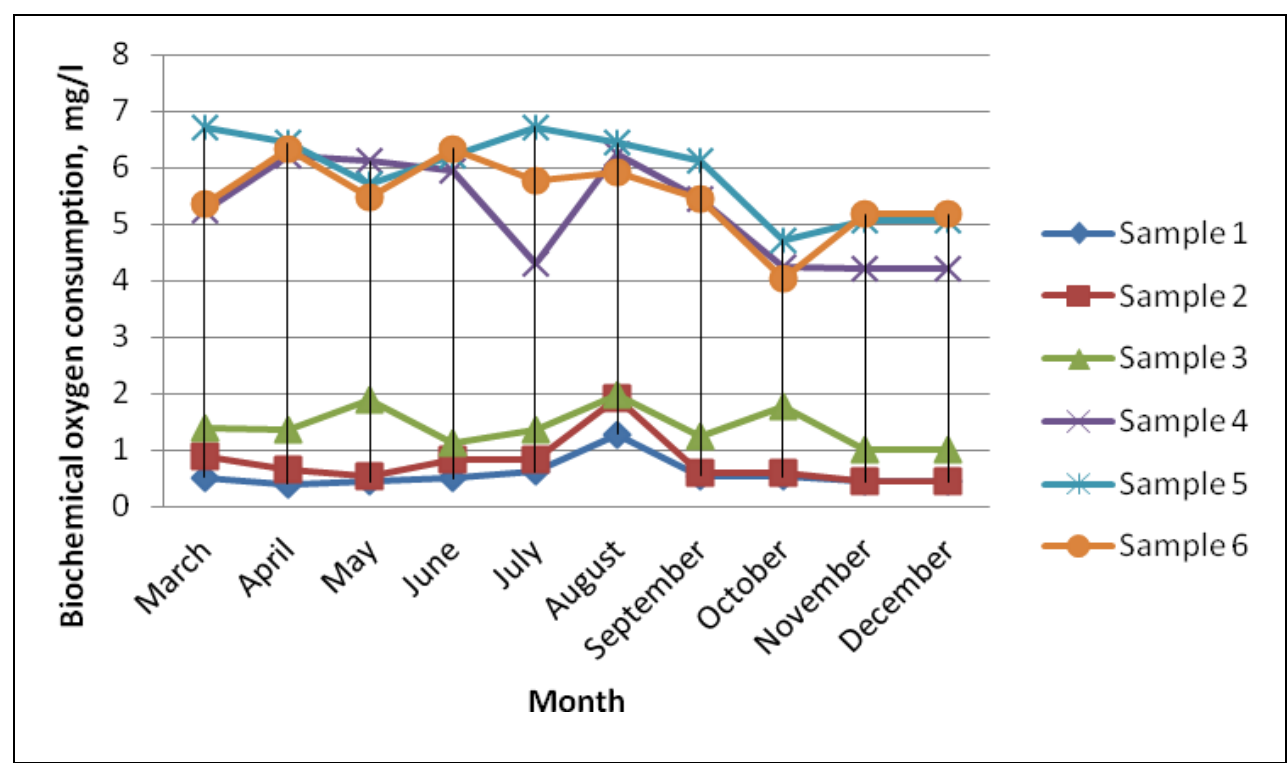

Figure 27: $\mathrm{CBO}_{5}$ values during 10 months in the monitored points of the Cibin River.

In direct line with the biochemical oxygen consumption is the chemical oxygen expressed in $\mathrm{CCOCr}$, which is basically the amount of oxygen supplied to the oxidizing chemical decomposition of organic matter in the water, which is not biodegradable. This leads to the framing of the Cibin River into the first class of quality.

Because only green plants and some bacteria can split oxygen from water for aquatic animal through photosynthesis and similar processes, it is important that this element should exist in high amounts in the river. Oxygen is essential for most aquatic life in natural surface waters and because of that, dissolved oxygen is the most important water quality parameter to indicate the health of a water body. (Delft, 2002) 


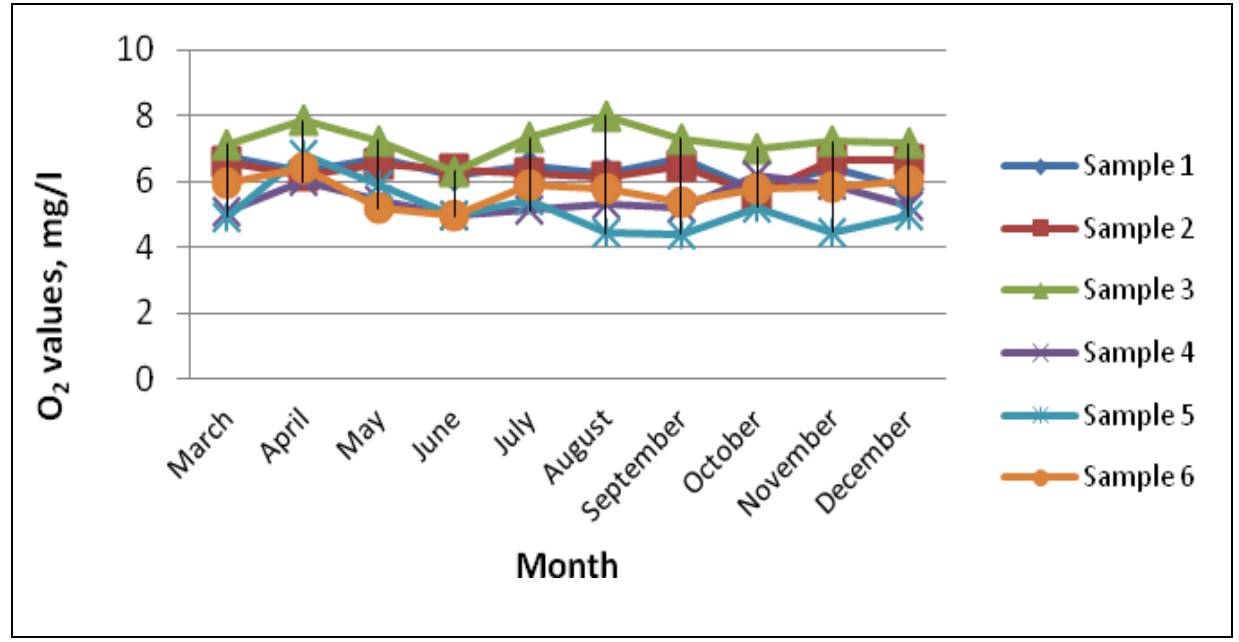

Figure 28: $\mathrm{O}_{2}$ values during 10 months in monitored points of the Cibin River.

The dissolved $\mathrm{O}_{2}$ ranges in the first quality class accepted limits for Cibin River and oscillates between $4.4 \mathrm{mg} / \mathrm{l}$ and $8 \mathrm{mg} / \mathrm{l}$. The most important quantities are found in the sources and dam reservoir decreasing with $30-40 \%$ to the Cibin River confluence area with Olt River.

\section{CONCLUSIONS}

After the study was made, it seems that Cibin River has physical-chemical and microbiological values which frame it in the first (sample points number 1,2 and 3) and second water quality class (sample points 4,5 and 6 ).

The river's sources, Râul Mare and Râul Mic lotic systems and Gura Râului Lake, are characterized by drinkable water specific parameters both in spring and autumn periods. Because there is a picnic place in the summer period, the human pollution increases especially the total coliform, nitrite, nitrate and suspensions. After the evaluation, all the elements above lead to an increase with $100 \%$ for the present values in spring and autumn.

The elements that define human settlements lead to significant increases of the phisical-chemical parameters like: nitrate, residues, $\mathrm{CBO}_{5}$ and $\mathrm{CCOCr}$ that frames Cibin River in the second quality class in its lower sections.

The tributary streams contribution from the mountain zone lead to a dilution on the outfall in Olt River section and the result frame Cibin River on the first quality class.

Because of the existence of the wastewater treatment plant of Sibiu, with significantly improved new technology, running at optimal parameters, some water pollution parameters are decreasing substantially lately. It is noticed that there are significant differences between the parameters determined downstream the wastewater treatment plant and upstream of it.

By the fact that the principal source of drinkable water of Sibiu is the upstream dam reservoir from Gura Râului, there is a certainty that this water presents optimal characteristics for human consumption and is declared one of the healthiest water from Romania.

In order to reduce human contamination, the implementation of educational programs is recommended, so that the negative human impact on the natural sources of water to be minimal. 


\section{ACKNOWLEDGMENTS}

This study is part of the research plan "Studies on drinking water in the Center Area of Romania", developed in the Centre for Research in Biotechnology and Microbiology at "Lucian Blaga" University of Sibiu under the coordination of Mrs. L. Oprean. 


\section{REFERENCES}

1. Abida B. and Harikrishna M., 2008 - Study on the Quality of Water in Some Streams of Cauvery River, E-Journal of Chemistry, 5, 2, 377-384.

2. Ashbolt N. J., 2004 - Microbial contamination of drinking water and disease outcomes in developing regions, Toxicology, 198, 229-238.

3. Balzer M., Witt N., Flemming H. C., Abida B. and Harikrishna Wingender J., 2010 - Faecal indicator bacteria in bio films, Water Science and Technology, 61, 5, 1105-11.

4. Blanch A. R., Belanche-Muñoz L., Bonjoch X., Ebdon J., Gantzer C., Lucena F., Ottoson J., Kourtis C., Iversen A., Kühn I., Moce L., Muniesa M., Schwartzbrod J., Skraber S., Papageorgiou G., Taylor H. D., Wallis J. and Jofre J., 2004 - Tracking the origin of faecal pollution in surface water: an ongoing project within the European Union research programme, Journal of Water Health, 2, 249-260.

5. Boon P. J., Calow P. and Petts G. E., 1992 - Essential elements in the case for river conservation, River Conservation and Management, Chichester: John Wiley \& Sons Ltd., 9-30.

6. Bucknell D. G., Gasser R. B., Irving A. and Whithear K., 1997 - Antimicrobial resistance in Salmonella and Escherichia coli isolated from horses, Austrian Veterinary Journal, 75, 355-356.

7. Carstenen J., 2007 - Statistical principles for ecological status classification of Water Framework Directive monitoring data, Marine Pollution Bulletin, 55, 3-15.

8. Cumming G. S., Cumming D. H. and Redman C. L., 2006 - Scale mismatches in socialecological systems: causes, consequences and solutions, Ecology and Society, 11(1), 14.

9. Delft Hydraulics and DHV Consultants BV, 2002 - Oxygen balance in Surface Waters, Hydrology Project Training Module.

10. Donovan E., Unice K., Roberts J. D., Harris M. and Finley B., 2008 - Risk of gastrointestinal disease associated with exposure to pathogens in the water of the lower Passaic River, Applied and Environmental Microbiology, 74, 994-1003.

11. Edwards A. C. and Withers P. J. A., 2008 - Transport and delivery of suspended solids, nitrogen and phosphorus from various sources to freshwaters in the UK, Journal of Hydrology, 350, 144-153.

12. Environment Agency, 2006 - Diffuse pollution and the Water Framework Directive, December.

13. Eleria A. L., 2002 - Forecasting Fecal Coliform Bacteria in the Charles River Basin, Master's Thesis, Tufts University, Medford, Massachusetts, 5-38.

14. Folland C. K., Karl T. R. and Christy J. R., 2001 - Observed climate variability and change, in: Climatic Change 2001: The Scientific Basis, Contribution of Working Group I to the Third Assessment Report of the IPCC (eds Houghton J. T., Ding Y., Griggs D. J., Noguer M., van der Linden P. J., Dai X., Maskell K. and Johnson C. A.), 101-181, Cambridge University Press, Cambridge, UK (http://www.grida.no/climate/ipcc_tar/wg1/index.htm).

15. Gurzău A. E., Popovici E., Pintea A., Popa O., Pop C. and Dumitraşcu I., 2010 - Quality of surface water sources from a Central Transylvanian area as a possible problem for human security and public health, Carpathian Journal of Earth and Environmental Sciences, 5, 2, 119-126.

16. Heathwaite A. L., Quinn P. F. and Hewett C. J. M., 2005b - Modelling and managing critical source areas of diffuse pollution from agricultural land using flow connectivity simulation, Journal of Hydrology, 204, 446-461.

17. Kallis G. and Butler D., 2001 - The E. U. water framework directive: measures and implications, Water Policy, 3, 125-142

18. Kaur S. and Mehra P., 2011 - Status of water quality of River Yamuna at Nigambodh ghat-a major cremation ground in Delhi, India, International Journal of Advances in Engineering, 2, 183-187. 
19. Kumar A. Y. and Reddy M. V., 2009 - Assessment of seasonal effects of municipal sewage pollution on the water quality of an urban canal - a case of Buckingham canal at Kalpakkam (India): $\mathrm{NO}_{3}^{-}, \mathrm{PO}_{4}^{3-}, \mathrm{SO}_{4}^{2-}, \mathrm{BOD}, \mathrm{COD}$ and DO, Environmental Monitoring and Assessment, 157, 1-4, 223-234.

20. Malmqvist B. and Rundle S., 2002 - Threats to the running water ecosystems of the world, Environmental Conservation, 29, 2, 134-153.

21. Medema G. J., Bahar M. and Schets F. M., 1997 - Survival of Cryptosporidium parvum, Escherichia coli, faecal enterococci and Clostridium perfrigens in river water: influence of temperature and autochthonous microorganisms, Water Science and Technology, 35, 11-12, 249-252.

22. Meyer J. L., Paul M. J. and Taulbee W. K., 2005 - Stream ecosystem function in urbanizing landscapes, Journal of the North American Benthological Society, 24, 3, 602-612.

23. Milanović A., Milijašević D. and Brankov J., 2011 - Assessment of polluting effects and surface water quality using water pollution index: case study of hydro-system Danube-TisaDanube, Serbia, Carpathian Journal of Earth and Environmental Sciences, 6, 2, 269-277.

24. Muyasar L. A. F. M., 2004 - Microbial Water Quality in Nablus District Thesis, Microbial Water Quality in Nablus District.

25. Osibanjo O., Daso A. P. and Gbadebo A. M., 2011 - The impact of industries on surface water quality of River Ona and River Alaro in Oluyole Industrial Estate, Ibadan, Nigeria, African Journal of Biotechnology, 10, 4, 696-702.

26. Parmesan C. and Yohe G., 2003 - A globally coherent fingerprint of climate change impacts across natural systems, Nature, 421, 37-42.

27. Patoli A. A., Patoli B. B. and Mehraj V., 2010 - High prelevance of multi-drug resistant Escherichia coli in drinking water samples from Hyderabad, Gomal Journal of Medical Sciences, 8, 1, 23-26.

28. Peters D. P. C., Groffman P. M., Nadelhoffer N. B., Collins S. L., Michener W. K. and Huston M. A., 2008 - Living in an increasingly connected world: a framework for continental scale environmental science, Frontiers in Ecology and the Environment, 6, 229237.

29. Petersen T. M., Rifai H. S., Suarez M. P. and Stein A. R., 2005 - Bacterial loads from point and nonpoint sources in an urban watershed, Journal of Environmental Engineering, 131, 10, 1414.

30. Peterson D. H., Smith R. E., Hager S. W., Harmon D. D., Herndon R. E. and Schemel L. E., 1985 - Interannual variability in dissolved inorganic nutrients in northern San Francisco Bay estuary, Hydrobiologia, 129, 37-58.

31. Pickett S. T. A., Cadenasso M. L., Grove J. M., Nilon C. H., Pouyat R. V., Zipperer W. C. and Costanza R., 2001 - Urban ecological systems: linking terrestrial ecological, physical, and socioeconomic components of metropolitan areas, Annual Revue of Ecology and Systematics, 32, 127-57.

32. Pietilainen O. P. and Niinioja R., 2001 - Nitrogen and phosphorus as algal growth limiting factors in a boreal lake, International Association of Theoretical and Limnology, 27, 29442947.

33. Podgornik M. and Pintar M., 2007 - Causes of nitrate leaching from agriculture land in Slovenia, Acta Agriculturae Slovenica, 89, 207-220.

34. Rajkumar S., Velmurugan P., Shanthi K., Ayasamy P. M. and Lakshmanaperumalasamy P., 2004 - Water Quality of Kodaikanal lake, Tamilnadu in Relation to Physico-Chemical and Bacteriological Characteristics, Capital Publishing Company, 339-346.

35. Rasmussen P. P. and Ziegler A. C., 2003 - Comparison and Continuous Estimates of Fecal Coliform and Escherichia Coli Bacteria in Selected Kansas Streams, May 1999 Through April 2002 - US Geological Survey Water Resources Investigations Report OS4056, Lawrence, Kansas, 80. 
36. Robert J. D. and Rutger R., 2008 - Spreading Dead Zones and Consequences for Marine Ecosystems, Science, 321, 5891, 926-929.

37. Rose S. and Peters N. E., 2001 - Effects of urbanization on streamflow in the Atlanta area (Georgia, USA): a comparative hydrological approach, Hydrological Processes, 15, 1441-57.

38. Sandu M., 1998 - Culoarul Depresionar Sibiu-Apold, Studiu geomorphologic, Editura Academiei Bucureşti, 176.

39. Sandu C., Bloesch J. and Coman A., 2008 - Water pollution in the Mureş catchment and its impact on the aquatic communities (Romania), Transylvanian Review of Systematical and Ecological Research, The Wetlands Diversity, Curtean-Bănăduc et al., (eds) 6, 97-108.

40. Sangodoyin A. Y., 1991 - Groundwater and Surface Water Pollution by Open Refuse Dump in Ibadan, Nigeria, Journal of Discovery and Innovations, 3, 1, 24-31.

41. Sanja M. S., Dragana S. D. and Dragan D. M., 2009 - Trace elements as tracers of environmental pollution in the canal sediments (alluvial formation of the Danube River, Serbia), Environmental Monitoring and Assessment, cited references, 167, 219-233.

42. Schriewer A., Miller W. A., Byrne B. A., Miller M. A., Oates S., Hardin D., Yang H. H,. Melli A., Jessup D., Dominik C. and Wuertz S., 2010 - Presence of Bacteroidales as a predictor of pathogens in surface waters of the Central California Coast, Applied and Environmental Microbiology, 76, 17, 5802-14.

43. Shrikanta N., 2005 - Studies on pollution status of Bondamunda area of Rourkela industrial complex, Department of Chemistry, National Institute of Technology, Rourkela - 769008 (Orissa).

44. Steyaert P. and Ollivier G., 2007 - How ecological assumptions frame technical and social change, Ecology and Society, 12, 1-18.

45. US Environmental Protection Agency (EPA), 2001b - Controlling Disinfection byproducts and Microbial Contaminants in Drinking Water, EPA.

46. Venkatesharaju K., Ravikumar P., Somashekar R. K. and Prakash K. L., 2010 - Physicochemical and bacteriological investigation on the river stretch in Karn, Kathmandu University Journal of Science, Engineering and Technology, 6, 1, 50-59.

47. World Health Organization (WHO), 1997 - Guidelines for drinking water quality: Surveillance and control of community supply, Geneva, 2, 2.

48. WHO and UNICEF, 2004 - Meeting the Millennium Development Goals (MDG) Drinking Water and Sanitation target - A mid-term Assessment of Progress, WHO/UNICEF, Geneva, $1-47$. 